\title{
Asset Pricing in Developed and Emerging Markets: A Survey
}

\author{
Shabir Ahmad Hakimª , Azhar Mohamad ${ }^{\mathrm{b} *}$ \\ ${ }^{a}$ Department of Finance, Effat University, Jeddah, Saudi Arabia \\ ${ }^{b}$ Department of Finance, KENMS, International Islamic University Malaysia, 53100 Kuala Lumpur, Malaysia \\ *Corresponding author: dr@azharmohamad.asia; m.azhar@iium.edu.my
}

\begin{abstract}
Asset pricing theory states that investors should be rewarded for the risks that are associated with the state variables, in addition to market risks, which affect their investment opportunity sets. The state variables, however, are latent variables that vary (a) within developed markets (which consist of segmented and international markets); (b) between developed and emerging markets. In this paper, we provide an evaluation of the development of asset pricing theory and an identification of factors that are pervasive and priced in both developed and emerging markets. This survey of the literature suggests there is a need for distinctive asset pricing models that consider the unique characteristics of both markets.
\end{abstract}

Keywords: Asset pricing; international asset pricing; developed markets; emerging markets; literature review.

\begin{abstract}
Abstrak
Teori penentuan harga aset menyatakan bahawa pelabur perlu diberi ganjaran bagi risiko yang diambil berkaitan dengan pemboleh ubah mengikut keadaan, di samping risiko pasaran, yang memberi kesan terhadap set peluang pelaburan mereka. Pemboleh ubah keadaan, bagaimanapun, adalah pembolehubah terpendam yang berubah-ubah di ( a) dalam pasaran maju (yang terdiri daripada pasaran bersegmen dan antarabangsa); (b ) antara pasaran maju dan baru muncul. Dalam kertas ini, kami menyediakan penilaian terhadap pembangunan teori penentuan harga aset dan mengenal pasti faktor-faktor yang meresap dan berharga dalam kedua-dua pasaran maju dan baru muncul. Tinjauan litratur ini mencadangkan terdapat keperluan untuk mencipta model penentuan harga aset tersendiri yang mengambil kira ciri-ciri unik kedua-dua pasaran tersebut.
\end{abstract}

Kata Kunci: Penentuan harga asset; penentuan harga asset antarabangsa; pasaran maju; pasaran baru muncul; tinjauan litratur.

(C) 2016 Penerbit UTM Press. All rights reserved

\subsection{INTRODUCTION}

Asset pricing theory states that investors should be rewarded for the systematic risks they bear when investing in risky assets (Sharpe, 1964). It facilitates the identification and quantification of risks associated with investing in different types of assets, the assessment of compensation for bearing those risks, the rationalization of differences in returns on different assets, and the realization of the time-varying nature of the asset returns (Harvey, 1995)

Asset pricing theory came into being with the introduction of the capital asset pricing model (CAPM) for the United States (US) market by William Sharpe (1964). CAPM is a single-factor static model that assumes that investors are single-period utility maximizers and that the market portfolio is sufficient to explain the returns on any risky asset. However, investors are multi-period utility maximizers, who base their investment decisions on the expected returns in the current as well as future periods (Merton, 1973). This, together with the observance of the return relevance of factors other than the market portfolio, directed asset pricing research towards establishing multifactor models. Merton (1973) suggests the addition of state variables that affect investors' investment sets over time, whereas Ross (1976) asserts that multiple mean-zero factors drive the asset returns. However, neither the state variables nor the mean-zero factors are identified. Many studies, such as Chen et al. (1986) and Fama and French (1993), fill the gap by proposing alternative multifactor models that select factors a priori. The studies do not claim that the modelled factors are exhaustive.

The expansion of markets in developed nations outside the US, in the early 1970s, offering investors alternative investment destinations, exposed the latter to an additional source of risk in the form of exchange rate risk (Solnik, 1974). Investors in such markets, whose investment opportunities differ across markets (Stulz, 1984), use different indices to assess the value of assets, and may arrive at different values for the same asset (Adler and Dumas, 1983). The models proposed by these studies assume full integration with the US market, replace local market portfolios with the global market portfolio and incorporate the exchange rate as a state variable.

In recent decades, emerging markets have attracted investors from all over the world. They are structurally different from and partially integrated with the developed markets, which necessitates the customization of asset pricing models to the local settings. Initial studies in emerging markets emphasized sovereign risk, while later studies have focused on the uniqueness of the drivers of risk in these markets. However, not only is the use of sovereign risk as the additional source of risk of investing in emerging markets contentious, but also the uniqueness of the other factors that are the same as those used in emerging markets is yet to be fully explored. 
In this paper, we review the literature on asset pricing modelling. We divide the literature into two parts: asset pricing in developed markets and asset pricing in emerging markets. Studies in the context of developed markets are further divided into those on the segmented US market and those in international markets.

\subsection{ASSET PRICING IN DEVELOPED MARKETS}

Asset pricing theory emerged in the US market with the introduction of the CAPM by William Sharpe. The US-based studies not only lay out a theoretical framework of asset pricing but also identify a number of factors that are pervasive in stock returns. Subsections 2.1 to 2.5 of this paper discuss theoretical asset pricing models and the remaining subsections present the empirical models.

\section{The Capital Asset Pricing Model (CAPM)}

Sharpe (1964) put forth a market equilibrium theory of asset prices under the condition of uncertainty. The theory is also known as the CAPM and extends Markowitz's (1952) mean variance theory (MVT) by adding two assumptions: (1) investors can lend and borrow at a risk-free rate, and (2) investors have homogeneous expectations and evaluate investments identically by agreeing on their expected returns, standard deviations, and correlations. Sharpe acknowledges the restrictive and unrealistic nature of these assumptions.

Sharpe replaces Markowitz's efficient frontier or investment opportunity curve (IOC) with the capital market line (CML). He defines an investment universe that consists of a risk-free asset and an efficient portfolio on the CML. He adds that every stock is a component of at least one efficient portfolio on the CML; the proposition is fundamental to relating the prices of capital stocks to different types of risk. Using Markowitz's portfolio variance formula, he derives the standard deviation for portfolio $y$ that consists of risky asset $\mathrm{i}$ and its efficient portfolio p:

$$
\sigma_{y}=\sqrt{w^{2} \sigma_{i}^{2}+(1-w)^{2} \sigma_{p}^{2}+2 w(1-w) \rho_{i p} \sigma_{i} \sigma_{p}}
$$

where $\sigma_{\mathrm{y}}$ is the standard deviation of the portfolio of stock $\mathrm{i}$ and the efficient portfolio $\mathrm{p}, \mathrm{w}$ is the weight of investment in stock $\mathrm{i}$, (1 - w) is the weight of investment in efficient portfolio $p, \sigma_{\mathrm{i}}^{2}$ and $\sigma_{\mathrm{p}}^{2}$ are the variance of stock $\mathrm{i}$ and portfolio $\mathrm{p}$ respectively, and $\rho_{\mathrm{ip}}$ is the correlation between returns on $\mathrm{i}$ and p. $\sigma_{\mathrm{p}}$ is constant for all $\mathrm{i}$, while $\sigma_{\mathrm{i}}$ is asset specific. The expected return on portfolio y is

$$
E\left(r_{y}\right)=w E\left(r_{i}\right)+(1-w) E\left(r_{p}\right)
$$

Sharpe differentiates (...2) with respect to w to obtain the relationship between the change in the return on portfolio y and the change in its risk $i$, which represents the slope of the IOC, $\frac{\partial E\left(r_{y}\right)}{\partial \sigma_{y}}=\frac{E\left(r_{y}\right)-E\left(r_{i}\right)}{\sigma_{y}-\rho_{i y} \sigma_{i}}$. At the tangency point, for an efficient portfolio, w=0, $\sigma_{y}=\sigma_{p}$ and $r_{y}=r_{p}$, and the slope of IOC is equivalent to that of CML, $b=\frac{\left[E(r)-r_{f}\right]}{\sigma_{r}}$. Equating the two gives

$$
\frac{\rho_{i p} \sigma_{i}}{\sigma_{p}}=\left[\frac{E\left(r_{i}\right)-r_{f}}{E\left(r_{p}\right)-r_{f}}\right]
$$

In (... 3), $\frac{\rho_{\mathrm{ip}} \sigma_{\mathrm{i}}}{\sigma_{\mathrm{p}}}=\frac{\sigma_{\mathrm{ip}}}{\sigma_{\mathrm{p}}^{2}}=\beta_{\mathrm{i}}$, the standardized covariance of returns on $\mathrm{i}$ and $\mathrm{p}$ with respect to the variance of the tangency portfolio. The standard deviation of the stock return represents its total risk, a part of which is due to its relationship with the return on the efficient portfolio and is captured by the regression slope, $\beta_{\mathrm{i}}$. Sharpe terms this component of total risk the "systematic risk" that cannot be diversified away. The rest of the risk, the regression residual, is diversifiable, and he terms it the "unsystematic risk". Substituting $\beta_{i}$ for $\frac{\rho_{i p} \sigma_{i}}{\sigma_{p}}$ and rearranging terms in (... 3) yields the CAPM:

$$
E\left(r_{i}\right)=r_{f}+\beta_{i}\left[E\left(r_{p}\right)-r_{f}\right]
$$

The CAPM states that the price of an individual security is determined by a linear relationship between the magnitude of its systematic risk, $\beta$, and its expected returns. As unsystematic risk can be diversified away, it does not enter into the CAPM equation.

Markowitz (1952) proposes that the selection of securities can be simplified by the regressing of the rate of return of each security on the return on a general index. Lintner (1965) uses the market index in place of the general index, stating that investors evaluate each stock in terms of the linear relationship between its returns and those of the market index, such that

where $r_{M}$ is the return on the market index.

$$
E\left(r_{i}\right)=r_{f}+\beta_{i}\left[E\left(r_{M}\right)-r_{f}\right]
$$

\section{Extension of CAPM}

\section{Relaxation of the Assumption of Homogeneous Expectations of Investors}

Lintner (1965) relaxes the assumption of homogeneous expectations of investors. He establishes the equivalence of homogeneous and heterogeneous expectations by deriving stock prices on a per share basis. He contends that investors distribute funds among stocks in portfolios in such a way that they can maximize their portfolio returns per unit of risk. Differentiating excess returns per unit of risk with respect to the weights assigned to the securities in a portfolio, he obtains

$$
\mathrm{x}_{\mathrm{i}}=\theta \mathrm{w}_{\mathrm{i}} \sigma_{\mathrm{i}}^{2}+\theta \sum_{\mathrm{j} \neq \mathrm{i}}^{\mathrm{n}} \mathrm{w}_{\mathrm{j}} \sigma_{\mathrm{ij}}
$$

where $x_{i}=\left(r_{i}-r_{f}\right), \theta=\frac{x_{p}}{\sigma_{p}^{2}}$ or the excess return on the portfolio per unit of its variance, $\sigma_{i}^{2}$ is the variance of asset $i_{s}$ and $\sigma_{i j}$ is the covariance of asset $i$ with other assets in the portfolio. With respect to value, the excess return on stock i can be written as 


$$
x_{i}=\frac{V_{i}^{+}-V_{0 i}\left(1+r_{f}\right)}{V_{0 i}}
$$

where $\mathrm{V}_{\mathrm{i}}^{+}$is the end-of-period aggregate market value of stock $\mathrm{i}$, and $\mathrm{V}_{0 \mathrm{i}}$ is the aggregate market value of $\mathrm{i}$ at the beginning of the period. If $\sigma_{\mathrm{i}}^{* 2}$ and $\sigma_{\mathrm{ij}}^{*}$ represent the expected variance and covariance of $V_{\mathrm{i}}$, then combining (.. 6) and (... 7) gives

$$
\mathrm{V}_{0 \mathrm{i}}=\frac{\mathrm{V}_{\mathrm{i}}^{+}-\gamma\left(\mathrm{w}_{\mathrm{i}} \sigma_{\mathrm{i}}^{* 2}+\sum_{\mathrm{j} \neq \mathrm{i}} \sigma_{\mathrm{ij}}^{*}\right)}{\left(1+\mathrm{r}_{\mathrm{f}}\right)}
$$

where $\gamma=\theta \mathrm{V}_{0 \mathrm{i}}, \gamma$ represents "the market price of the dollar risk and is the same for all companies in the market in equilibrium" (Lintner, 1965, p. 599), and $\gamma\left(w_{i} \sigma_{i}^{* 2}+\sum_{j \neq i} \sigma_{i j}^{*}\right)$ corresponds to the market value of the total risk associated with the end-of-period aggregate value of stock i.

\section{Prices Under Homogeneous Expectations}

Assume that $\mathrm{N}_{\mathrm{i}}$ is the number of outstanding shares of stock $\mathrm{i}, \mathrm{P}_{0 \mathrm{i}}$ the current price per share of $\mathrm{i}$, and $\mathrm{P}_{\mathrm{i}}^{+}$the expected end-of-period price per share. It then follows that $\mathrm{V}_{0 \mathrm{i}}=\mathrm{N}_{\mathrm{i}} \mathrm{P}_{0 \mathrm{i}}$ and $\mathrm{V}_{\mathrm{i}}^{+}=\mathrm{N}_{\mathrm{i}} \mathrm{P}_{\mathrm{i}}^{+}$. Substituting the values of $\mathrm{V}_{0 \mathrm{i}}$ and $\mathrm{V}_{\mathrm{i}}^{+}$into (... 8) gives

or

$$
\mathrm{N}_{\mathrm{i}} \mathrm{P}_{0 \mathrm{i}}\left(1+\mathrm{r}_{\mathrm{f}}\right)=\mathrm{N}_{\mathrm{i}} \mathrm{P}_{\mathrm{i}}^{+}-\gamma\left[\mathrm{N}_{\mathrm{i}}^{2}(\text { var })_{\mathrm{i}}+\sum_{\mathrm{j} \neq 1} \mathrm{~N}_{\mathrm{i}} \mathrm{N}_{\mathrm{j}}(\text { cov })_{\mathrm{ij}}\right] \text {, }
$$

$$
\mathrm{P}_{0 \mathrm{i}}=\frac{\mathrm{P}_{\mathrm{i}}^{+}-\gamma\left[\mathrm{N}_{\mathrm{i}}(\text { var })_{\mathrm{i}}+\sum_{\mathrm{j} \neq 1} \mathrm{~N}_{\mathrm{j}}(\operatorname{cov})_{\mathrm{ij}}\right]}{\left(1+\mathrm{r}_{\mathrm{f}}\right)}
$$

where $(\text { var })_{i}$ is the variance per share of $i$ and $(\operatorname{cov})_{i j}$ equals the covariance per share.

\section{Prices Under Heterogeneous Expectations}

In equilibrium, the heterogeneous expectations of investors will affect how they assign weights to the end-of-period value of stock i, and its variance and covariance. Assuming K investors who hold stock i, they will be in equilibrium at a price at which (... 9) holds according to their individual expectations. Accordingly, the current price $\mathrm{P}_{0 \mathrm{i}}$ for stock i must satisfy the following equation for the $\mathrm{k}^{\text {th }}$ investor:

$$
\mathrm{P}_{\mathrm{i}(\mathrm{k})}^{+}-\mathrm{P}_{0 \mathrm{i}}\left(1+\mathrm{r}_{\mathrm{f}}\right)=\gamma_{\mathrm{k}}\left[\mathrm{N}_{\mathrm{i}(\mathrm{l})}(\operatorname{var})_{\mathrm{i}(\mathrm{k})}+\sum_{\mathrm{j} \neq 1} \mathrm{~N}_{\mathrm{j}(\mathrm{k})}(\operatorname{cov})_{\mathrm{ij}(\mathrm{k})}\right]
$$

where $\gamma_{k}=R_{k} / \operatorname{var}(k), R_{k}$ is the aggregate return on the portfolio of investor $k$, and $\operatorname{var}(k)$ is the variance of the end-of-period value of the portfolio of investor $k$. Replacing $\gamma_{\mathrm{l}}$ with $\mathrm{R}_{\mathrm{k}} / \operatorname{var}(\mathrm{k})$ in (... 10) yields

Adding up all investors in the market for stock i gives

$$
\operatorname{var}(\mathrm{k})\left[\mathrm{P}_{\mathrm{i}(\mathrm{k})}^{+}-\mathrm{P}_{0 \mathrm{i}}\left(1+\mathrm{r}_{\mathrm{f}}\right)\right]=\mathrm{R}_{\mathrm{k}}\left[\mathrm{N}_{\mathrm{i}(\mathrm{l})}(\operatorname{var})_{\mathrm{i}(\mathrm{k})}+\sum_{\mathrm{j} \neq \mathrm{i}} \mathrm{N}_{\mathrm{j}(\mathrm{k})}(\operatorname{cov})_{\mathrm{ij}(\mathrm{k})}\right]
$$

$$
\begin{gathered}
\sum_{k} \operatorname{var}(k)\left[P_{i(k)}^{+}-P_{0 i}\left(1+r_{f}\right)\right]=\sum_{k} R_{k}\left[N_{i(k)}(\operatorname{var})_{i(k)}+\sum_{j \neq i} N_{j(k)}(\operatorname{cov})_{i j(k)}\right] \\
\equiv P_{0 i}\left(1+r_{f}\right)=P_{i(k)}^{+}-\frac{\sum_{k} R_{k}}{\sum_{k} \operatorname{var}(k)}\left[N_{i(k)}(\operatorname{var})_{i(k)}+\sum_{j \neq i} N_{j(k)}(\operatorname{cov})_{i j(k)}\right]
\end{gathered}
$$

which reduces to

$$
\mathrm{P}_{0 \mathrm{i}}\left(1+\mathrm{r}_{\mathrm{f}}\right)=\frac{\operatorname{var}(\mathrm{k})}{\sum_{\mathrm{k}} \operatorname{var}(\mathrm{k})} \mathrm{P}_{\mathrm{i}}^{+}-\gamma\left[\mathrm{N}_{\mathrm{i}}(\operatorname{var})_{\mathrm{i}}+\sum_{\mathrm{j} \neq \mathrm{i}} \mathrm{N}_{\mathrm{j}}(\operatorname{cov})_{\mathrm{ij}}\right]
$$

where

$\mathrm{P}_{\mathrm{i}}^{+}=\sum_{\mathrm{l}} \mathrm{P}_{\mathrm{i}(\mathrm{k})}^{+}$represents the sum of individual investors' expected end-of-period prices;

$\gamma=\frac{\sum_{\mathrm{k}} \mathrm{R}_{\mathrm{k}}}{\sum_{\mathrm{k}} \operatorname{var}(\mathrm{k})}$ aggregates the excess return per unit of risk on investors' portfolios;

$\mathrm{N}_{\mathrm{i}}(\operatorname{var})_{\mathrm{i}}=\left[\sum_{\mathrm{l}} \mathrm{N}_{\mathrm{i}(\mathrm{k})}(\mathrm{var})_{\mathrm{i}(\mathrm{k})}\right]$ is the sum of individual investors' variance of stock i divided by the overall variance of stock $\mathrm{i}$; and $\mathrm{N}_{\mathrm{j}}(\mathrm{cov})_{\mathrm{ij}}=\left[\sum_{\mathrm{l}} \mathrm{N}_{\mathrm{j}(\mathrm{k})}(\mathrm{cov})_{\mathrm{ij}(\mathrm{k})}\right]$ is the sum of individual investors' covariance divided by the overall covariance of stock $\mathrm{i}$ with stock $\mathrm{j}$.

From (... 11) it follows that the current price per share of stock i has two components: (1) the end-of-period price and (2) the variance of the stock priced at dollar risk, $\gamma$. The weights of the end-of-period prices correspond to the variances of the entire portfolios of different investors, while those attached to stock i's contribution to the variance of the portfolio correspond to the expected returns on the portfolios of different investors. As in (...9), $\gamma$ represents the market price of risk. It follows that the ratio of aggregate end-of-period returns, for all stocks and investors, to the aggregate variance of all stocks in all portfolios is the same under both homogeneous and heterogeneous expectations.

\section{Relaxation of the Assumption of Riskless Lending and Borrowing}

Black (1972) relaxes the assumption of risk-free lending and borrowing by demonstrating the equivalence of CAPM and the Jensen, Black and Scholes (1972) two-factor model. The two-factor model, which assumes the absence of risk-free lending and borrowing, is of the form

$$
r_{i}=\alpha_{i}+\beta_{i} r_{M}+\left(1-\beta_{i}\right) r_{z}+\varepsilon_{i}
$$

where $r_{M}$ and $r_{z}$ are the returns on the market portfolio and the zero-beta portfolio, and $r_{z}$ is independent of $r_{M}$. He assumes that, in the absence of risk-free lending and borrowing, investors can take a long or short position of any size in any risky asset, an assumption he 
acknowledges is unrealistic. He contends that investor $\mathrm{k}$ constructs an efficient portfolio by investing in stock $\mathrm{i}(\mathrm{i}=1,2, \ldots, \mathrm{N}) \mathrm{using}$ weights of $\mathrm{w}_{\mathrm{ik}}$ in order to

$$
\text { Minimize } \sigma_{\mathrm{k}}^{2}=\sum_{\mathrm{i}=1}^{\mathrm{N}} \sum_{\mathrm{j}=1}^{\mathrm{N}} \mathrm{w}_{\mathrm{ik}} \mathrm{w}_{\mathrm{jk}} \sigma_{\mathrm{ij}}
$$

Subject to:

$$
\begin{gathered}
\sum_{i=1}^{N} w_{i k} E\left(r_{i}\right)=E\left(r_{k}\right) ; \\
\sum_{i=1}^{N} w_{i k}=1
\end{gathered}
$$

where $\sigma_{\mathrm{k}}^{2}$ is the variance the portfolio of investor $\mathrm{k}(\mathrm{k}=1,2, \ldots, \mathrm{K})$ and $\mathrm{w}_{\mathrm{ik}}$ represent the weights assigned to stock $\mathrm{i}(\mathrm{i}=1,2, \ldots, \mathrm{N})$ in the efficient portfolio held by investor $\mathrm{k}$. He obtains the weights assigned to the stocks by applying Lagrange multipliers $\lambda_{1 \mathrm{k}}$ and $\lambda_{2 \mathrm{k}}$ and differentiating with respect to $\mathrm{w}_{\mathrm{ik}}$ :

$$
w_{j k}=\lambda_{1 k} \sum_{j=1}^{N} v_{i j} E\left(r_{i}\right)+\lambda_{2 k} \sum_{j=1}^{N} v_{i j}
$$

where $v_{i j}$ is the inverse of $\sigma_{i j}$. The reference to investor $\mathrm{k}$ in (... 14) attaches to the Lagrange multipliers only, which signifies that investor $\mathrm{k}$ can create portfolios from two basic portfolios. Black asserts that it is not necessary that the weights of individual assets in a portfolio sum to 1 . Therefore, he normalizes (... 14) to obtain

$$
\mathrm{w}_{\mathrm{ik}}=\mathrm{y}_{\mathrm{Sk}} \mathrm{w}_{\mathrm{iS}}+\mathrm{y}_{\mathrm{Tk}} \mathrm{w}_{\mathrm{iT}}
$$

where $\mathrm{S}$ and $\mathrm{T}$ are the two basic portfolios, $\mathrm{y}_{\mathrm{Sk}}$ and $\mathrm{y}_{\mathrm{Tk}}$ denote investor k's proportion of investment in portfolios $\mathrm{S}$ and $\mathrm{T}$, respectively, and $\mathrm{w}_{\mathrm{iS}}$ and $\mathrm{w}_{\mathrm{iT}}$ denote the weights of stock $\mathrm{i}(\mathrm{i}=1,2, \ldots, \mathrm{N})$ in portfolios $\mathrm{S}$ and $\mathrm{T}$, respectively. Furthermore, $\mathrm{y}_{\mathrm{Sk}}=\lambda_{1 \mathrm{k}} \sum_{\mathrm{i}=1}^{\mathrm{N}} \sum_{\mathrm{j}=1}^{\mathrm{N}} \mathrm{v}_{\mathrm{ij}} \mathrm{E}\left(\mathrm{r}_{\mathrm{i}}\right)$, $\mathrm{y}_{\mathrm{Tk}}=\lambda_{2 \mathrm{k}} \sum_{\mathrm{i}=1}^{\mathrm{N}} \sum_{\mathrm{j}=1}^{\mathrm{N}} \mathrm{v}_{\mathrm{ij}}, \mathrm{w}_{\mathrm{iS}}=\sum_{\mathrm{i}=1}^{\mathrm{N}} \mathrm{v}_{\mathrm{ij}} \mathrm{E}\left(\mathrm{r}_{\mathrm{i}}\right) / \sum_{\mathrm{i}=1}^{\mathrm{N}} \sum_{\mathrm{j}=1}^{\mathrm{N}} \mathrm{v}_{\mathrm{ij}} \mathrm{E}\left(\mathrm{r}_{\mathrm{i}}\right), \mathrm{w}_{\mathrm{iT}}=\sum_{\mathrm{i}=1}^{\mathrm{N}} \mathrm{v}_{\mathrm{ij}} / \sum_{\mathrm{i}=1}^{\mathrm{N}} \sum_{\mathrm{j}=1}^{\mathrm{N}} \mathrm{v}_{\mathrm{ij}}, \sum_{\mathrm{i}=1}^{\mathrm{N}} \mathrm{w}_{\mathrm{iS}}=1, \sum_{\mathrm{i}=1}^{\mathrm{N}} \mathrm{w}_{\mathrm{iT}}=1$, and $\mathrm{y}_{S \mathrm{Sk}}+$ $\mathrm{y}_{\mathrm{Tk}}=1$. It follows that $\mathrm{w}_{\mathrm{ik}}$ in $(\ldots 15)$ must also sum to 1 .

Black argues that it is possible to create new portfolios, with arbitrary betas, by choosing appropriate weights for the basic portfolios. Suppose, in an efficient portfolio $\mathrm{p}$, that the weights of the basic portfolios are chosen such that

$$
\beta_{\mathrm{X}}=1 \text { and } \beta_{\mathrm{Y}}=0
$$

If $\omega_{\mathrm{Mk}}$ is the fraction of total wealth in the market held by investor $\mathrm{k}$ then summing over all investors provides the weight for each asset in the market portfolio,

$$
w_{i M}=\left(\sum_{k=1}^{K} \omega_{M k} w_{S k}\right) w_{i S}+\left(\sum_{k=1}^{K} \omega_{M k} w_{T k}\right) w_{i T} ; \quad i=1,2, \ldots, N
$$

where $\mathrm{w}_{\mathrm{iM}}$ is the weight of asset $\mathrm{i}$ in market portfolio $\mathrm{M}, \omega_{\mathrm{Mk}}$ the proportion of wealth invested by each investor $\mathrm{k}$ in the market portfolio, $\mathrm{w}_{\mathrm{Uk}}$ and $\mathrm{w}_{\mathrm{Vk}}$ the weights assigned by investor $\mathrm{k}$ to portfolios $\mathrm{S}$ and $\mathrm{T}$, and $\mathrm{w}_{\mathrm{iU}}$ and $\mathrm{w}_{\mathrm{iV}}$ the weights of stock i in $\mathrm{S}$ and $\mathrm{T}$. Since the market portfolio is a weighted combination of the basic portfolios $S$ and $\mathrm{T}$, and the beta of the market portfolio, $\beta_{\mathrm{M}}$, is 1 , portfolio $\mathrm{X}$, in portfolio $\mathrm{p}$, should be a market portfolio and portfolio Y a zero-beta portfolio. Thus, the return on the efficient portfolio e can be written in the two-factor form as follows:

Taking expectations of (... 17) gives

$$
r_{p}=\beta_{p} r_{M}+\left(1-\beta_{p}\right) r_{z}
$$

$$
\mathrm{E}\left(\mathrm{r}_{\mathrm{p}}\right)=\mathrm{E}\left(\mathrm{r}_{\mathrm{z}}\right)+\beta_{\mathrm{p}}\left[\mathrm{E}\left(\mathrm{r}_{\mathrm{M}}\right)-\mathrm{E}\left(\mathrm{r}_{\mathrm{z}}\right)\right]
$$

That is, the expected return on efficient portfolio $p$ is a linear function of $\beta_{p}$. In the presence of a risk-free asset, the risk-free rate $r_{\mathrm{f}}$ replaces $\mathrm{E}\left(\mathrm{r}_{\mathrm{z}}\right)$, and $(\ldots 18)$ transforms into

$$
E\left(r_{p}\right)=r_{f}+\beta_{p}\left[E\left(r_{M}\right)-r_{f}\right]
$$

the CAPM. (... 19) is a clone of (.. 18) because, like portfolio $\mathrm{z}$, the riskless asset is a zero-beta asset. Hence, the expected returns on the efficient portfolio $\mathrm{p}$ are a linear function of $\beta_{\mathrm{p}}$ whether or not there is risk-free lending and borrowing. In fact, the two basic portfolios in (... 19) are the market portfolio and the risk-free asset. Black concludes that the two-factor model is as much applicable to individual securities as it is to efficient portfolios.

\section{Conditional Capital Asset Pricing Model Intertemporal Capital Asset Pricing Model}

Jagannathan and Wang (1996) argue that the single-period nature of the CAPM implies that the beta of the asset remains constant over time, while the cash flows of firms fluctuate over business cycles. As a result, the expected returns and betas are likely to vary over time and are conditional on the nature of information available at a given point in time. They propose a conditional CAPM of the form

$$
\mathrm{E}\left(\mathrm{r}_{\mathrm{it}} \mid \mathrm{I}_{\mathrm{t}-1}\right)=\delta_{0, \mathrm{t}-1}+\delta_{1, \mathrm{t}-1} \beta_{\mathrm{i}, \mathrm{t}-1}
$$

where $r_{i t}$ is the return on asset $i$ at time t contingent on the information I available at time $t-1, \delta_{0, t-1}$ is the conditional expected return on a zero-beta portfolio at time $\mathrm{t}-1$, and $\delta_{\mathrm{i}, \mathrm{t}-1}$ is the conditional market risk premium at time $\mathrm{t}-1 . \beta_{\mathrm{i}, \mathrm{t}-1}$ is the conditional beta of asset $\mathrm{i}$, defined as

$$
\beta_{i t-1}=\operatorname{Cov}\left(R_{i t}, R_{M t} \mid I_{t-1}\right) / \operatorname{var}\left(R_{M t} \mid I_{t-1}\right)
$$

Taking unconditional expectations of (... 20) to obtain the cross-sectional variation in the unconditional expected returns on different assets yields

$$
\mathrm{E}\left(\mathrm{r}_{\mathrm{it}}\right)=\gamma_{0}+\gamma_{1} \beta_{\mathrm{i}}+\operatorname{cov}\left(\gamma_{1 \mathrm{t}-1}, \beta_{\mathrm{it}-1}\right)
$$


where $\gamma_{0}=\mathrm{E}\left(\gamma_{0, \mathrm{t}-1}\right), \gamma_{1}=\mathrm{E}\left(\gamma_{1, \mathrm{t}-1}\right)$, and $\beta_{\mathrm{i}}=\mathrm{E}\left(\beta_{\mathrm{i}, \mathrm{t}-1}\right) \cdot \gamma_{1}$ is the market risk premium and $\beta_{\mathrm{i}}$ is the market beta of asset $\mathrm{i}$. In the case where the covariance between the conditional market risk premium and the conditional asset beta is zero, (... 21) collapses to the static CAPM; however, they are generally correlated.

Intertemporal Capital Asset Pricing Model

Merton (1973) argues that the CAPM is a single-factor, single-period model, whereas investors make investment decisions based on expected returns in current as well as future periods in order to maximize the utility of their lifetime consumption. He proposes a multi-period version of the CAPM known as the intertemporal capital asset pricing model (ITCAPM). The ITCAPM states that investors make investment decisions based on the transition probability of returns on each asset in the investment opportunity set in the next period and the transition probability of returns on the stocks in future periods. The model allows for changes in the investment opportunity set over time.

Merton's ITCAPM investment universe consists of an instantaneous riskless asset and $\mathrm{n}$ distinct risky assets. An asset is said to be instantaneously riskless if investors, at any instant, are certain about its expected returns in the next instant; i.e., they can earn the risk-free rate of return with zero variance. A distinct asset is an asset whose return is not a linear combination of the returns on the other assets. To derive the demand function for asset $\mathrm{i}$ for investor $\mathrm{k}$, Merton treats the risk-free rate as a state variable and assumes the nth asset to be perfectly negatively correlated with the instantaneous risk-free rate, such that the demand for asset $i$ from investor $k$, $d_{i}^{k}$, equals

$$
d_{i}^{k}=A^{k} \sum_{1}^{n} v_{i j}\left(r_{i}-r_{f}\right)+H^{k} \sum_{1}^{n} v_{i j} \sigma_{j r f}
$$

where the first term represents a single-period utility maximizer's demand function for the risky assets, and A is the reciprocal of the investor's absolute risk aversion. The second term in the equation represents the demand for the assets for hedging against unfavourable shifts in the investment opportunity set, where $\mathrm{H}^{\mathrm{k}}$ is the hedge portfolio of investor $\mathrm{k}$. $\sigma_{\mathrm{jrf}}$ is the instantaneous covariance between the return on asset $\mathrm{j}$ and changes in the risk-free rate. For the nth asset, $\rho_{\mathrm{nrf}}=-1$, hence $\sigma_{\mathrm{jrf}}$ in $(\ldots 17)$ equals $-\mathrm{g}\left(\sigma_{\mathrm{jn}}\right) / \sigma_{\mathrm{n}}$, where $\mathrm{g}$ is the standard deviation of the changes in $r_{f}$ and the second term in (.. 17) can be written as $-g H^{k} / \sigma_{n}$. For another asset, (n-1), it is equal to zero. From (... 17), the aggregate demand for stock $\mathrm{i}$ is obtained by summing up the demand of all investors:

$$
\begin{aligned}
& D_{i}=A \sum_{i=1}^{n} v_{i j}\left(r_{i}-r_{f}\right)-g H / \sigma_{n} \text { for } n \text {th stock } \\
& D_{i}=A \sum_{i=1}^{n} v_{i j}\left(r_{i}-r_{f}\right) \text { for } n-1 \text { stocks }
\end{aligned}
$$

where $D_{i}$ is the aggregate demand for $i$ in the market, $D_{i}=\sum_{1}^{K} d_{i}^{k}$, with $K$ the number of investors, $A=\sum_{1}^{K} A^{k}$ and $H=\sum_{1}^{K} H^{k}$. The aggregate of $D_{i}$ for all stocks represents the demand for or value of all stocks in the market at equilibrium, or $\sum_{i=1}^{n+1} D_{i}=M$; in other words, $D_{i} / M$ represents the proportional contribution made by stock $i$ to the overall market. Substituting $w_{i} / M$ for $D_{i}$ in (... 23), Merton obtains the equilibrium expected return on individual assets:

$$
r_{i}=r_{f}+\left(\frac{M}{A}\right) \sum_{i=1}^{n} w_{i} \sigma_{i j}+\left(\frac{H g}{A \sigma_{n}}\right) \sigma_{i n}
$$

Given the return on the market, $r_{M}=\sum_{i=1}^{n} w_{i}\left[E\left(r_{i}\right)-r_{f}\right]+r_{f}$, its variance, $\sigma_{M}^{2}=\sum_{i=1}^{n} w_{i} \sigma_{i M}$, and covariance, $\sigma_{i M}=\sum_{i=1}^{n} w_{i} \sigma_{i j},(\ldots 24)$ can be rewritten as

$$
r_{i}-r_{f}=\left(\frac{M}{A}\right) \sigma_{i M}+\left(\frac{H g}{A \sigma_{n}}\right) \sigma_{i n}
$$

From (... 25), excess returns on the market are obtained by multiplying the equation by $\mathrm{w}_{\mathrm{i}}$ and summing:

$$
r_{M}-r_{f}=\left(\frac{M}{A}\right) \sigma_{M}^{2}+\left(\frac{H g}{A \sigma_{n}}\right) \sigma_{M n}
$$

If the nth asset satisfies (...25), then it can be usedalong with (.. 26) to rewrite (...25) as

$$
r_{i}-r_{f}=\frac{\sigma_{i}\left[\rho_{i M}-\rho_{i n} \rho_{n M}\right]}{\sigma_{M}\left[1-\rho_{n M}^{2}\right]}\left(r_{M}-r_{f}\right)+\frac{\sigma_{i}\left[\rho_{i n}-\rho_{i M} \rho_{n M}\right]}{\sigma_{n}\left[1-\rho_{M n}^{2}\right]}\left(r_{n}-r_{f}\right)
$$

From equation (... 27), it follows that, in equilibrium, the expected return compensates investors for systematic risk and risks associated with unfavourable changes in the investment opportunity set. Merton calls this the "natural generalization of the security market line of the classical capital asset pricing model” (p.882). Extending (... 27) to s state variables gives

$$
r_{i}-r_{f}=\beta_{i}\left[r_{M}-r_{f}\right]+\sum_{s=1}^{S} \beta_{s}\left[r_{s}-r_{f}\right]
$$

where $\beta_{\mathrm{i}}$ and $\beta_{\mathrm{s}}$ represents the sensitivities of the return on stock $i$ to the returns on market and state variables, respectively.

\section{Arbitrage Pricing Theory (APT) Number of Factors in a Model}

Ross (1976) argues that the mean variance efficiency (MVE) of the market portfolio in the CAPM is hard to prove, theoretically as well as empirically. He proposes an alternate to the CAPM in the form of arbitrage pricing theory (APT). APT formulates a theory that relates to but is distinct from the classical MVT because (1) the model holds in equilibrium and disequilibrium situations, and (2) the market portfolio does not play any special role. Pertinently, APT retains the CAPM's intuition about investors' ability to hold well-diversified portfolios (Shanken, 1982). The APT defines returns on assets as follows:

$$
r_{i}=E\left(r_{i}\right)+\beta_{i 1} f_{1}+\cdots+\beta_{i k} f_{k}+\varepsilon_{i} \quad i=1,2, \cdots, n
$$


where $r_{i}$ is the return on asset $i$, the $f_{k}$ represent mean-zero common factors, i.e. $E\left(f_{k}\right)=0$, and $\beta_{i k}$ is the sensitivity of the return on $i$ to the common factor k. $\varepsilon_{\mathrm{i}}$ is the asset-specific mean-zero disturbance, i.e. $\mathrm{E}\left(\varepsilon_{\mathrm{i}}\right)=0 ; \varepsilon_{\mathrm{i}}$ are assumed to be independent across assets and of the common factors, $\mathrm{f}_{\mathrm{k}}$. APT does not impose any additional restrictions on the nature of the multivariate distribution of $\mathrm{f}$ and $\varepsilon$, except that the variance does not go out of bounds $(\exists \sigma<\infty)$.

\section{Assumptions of APT}

Connor (1984) develops a competitive-equilibrium version of the APT, which states that there exist optimal portfolios for all budgetconstrained investors and that the supply and demand of securities match. The model assumes that (1) the number of risky assets is finite, with the returns on assets obeying a linear k-factor model and having bounded variance, and (2) the model includes the market portfolio as a factor and assumes that it does not carry any unsystematic risk.

Connor assumes that, in a competitive equilibrium, there exists a factor-equivalent, well-diversified portfolio for any poorly diversified portfolio. Two portfolios are considered factor-equivalent if their expected payoffs and factor risks are identical despite their idiosyncratic risks being different. Furthermore, the comparison between finite and infinite market conditions relates to the presence of a fully diversified market portfolio with zero idiosyncratic risk, $\mathrm{E}\left(\varepsilon_{\mathrm{M}}^{2}\right)=0$. In a finite market, the asset supply has to be in such a proportion that the idiosyncratic risk of the market portfolio is eliminated, while, in an infinite market, the diversification is a natural outcome because the supply of individual assets is infinitesimal and the idiosyncratic risk disappears as per the law of large numbers. Connors, however, acknowledges the restrictive nature of the assumption requiring a well-diversified market portfolio in a finite market: "It is also nongeneric: a perturbation of asset supplies would almost surely destroy this property" (Connor, 1984, p. 28).

Wei (1988) extends Connor's model by relaxing the assumption of a well-diversified market portfolio. He proposes replacing assumption (2) in Connor's model with either of the following:

1. The relationship between the idiosyncratic risk of an asset, $\varepsilon_{\mathrm{i}}$, and that of the market portfolio, $\varepsilon_{\mathrm{M}}$, is

$$
\varepsilon_{\mathrm{i}}=\mathrm{b}_{\mathrm{iM}} \varepsilon_{\mathrm{M}}+\epsilon_{\mathrm{i}} \quad \ldots 30
$$

where $b_{i M}$ represents the sensitivity of the variance of asset $i$ to the variance of the market portfolio, and $\epsilon_{i}$ is orthogonal to $\varepsilon_{M}$.

2. The vector of factors, $f$, are independently distributed, of each other and of the vector of $\varepsilon ; E\left(\epsilon_{i} \mid \varepsilon_{M}\right)=0$ in $(\ldots 30)$.

Wei combines his assumptions with the assumptions of the competitive equilibrium model, and substitutes (... 30) into (... 29) to obtain the following extended competitive equilibrium version of APT:

Wei makes the following assertions about his model:

$$
r_{i}=E\left(r_{i}\right)+\beta_{i 1} f_{1}+\cdots+\beta_{i k} f_{k}+b_{i M} \varepsilon_{M}+\epsilon_{i} \quad \ldots 31
$$

i. All investors will hold well-diversified portfolios according to (... 31); this assertion follows from Connor's model, which states that investors prefer fully diversified portfolios to factor-equivalent portfolios.

ii. There exist $\mathrm{k}+2$ separating portfolios, which consist of $\mathrm{k}$ portfolios for $\mathrm{k}$ factors in (... 31), and one portfolio each for the riskless asset and the market portfolio.

iii. The expected return holds exactly in competitive equilibrium, i.e.,

$$
\mathrm{E}\left(\mathrm{r}_{\mathrm{i}}\right)=\delta_{0}+\beta_{\mathrm{i} 1} \delta_{1}+\cdots+\beta_{\mathrm{ik}} \delta_{\mathrm{k}}+\beta_{\mathrm{iM}} \delta_{\mathrm{M}} ; \quad \delta_{\mathrm{M}}>0
$$

Assertion (iii) is the distinctive characteristic of Wei's model, because it unifies APT and the CAPM. Besides the information contained in the relevant factors, the model uses information contained in the market portfolio. Wei also investigates the impact of omitted factors on asset pricing. With $\mathrm{j}$ factors in place of $\mathrm{k}(\mathrm{j}<\mathrm{k})$,

$$
r_{i}=E\left(r_{i}\right)+\beta_{i 1} f_{1}+\cdots+\beta_{i j} f_{j}+\varepsilon_{i}^{*}
$$

Assuming factor independence (assumption 2) and modified residuals of (... 30)

$$
\varepsilon_{\mathrm{i}}^{*}=\beta_{\mathrm{iM}}^{*} \varepsilon_{\mathrm{M}}^{*}+\epsilon_{\mathrm{i}}^{*} ; \quad \mathrm{E}\left(\epsilon_{\mathrm{i}}^{*} \mid \varepsilon_{\mathrm{M}}^{*}\right)=0,
$$

then, in competitive equilibrium,

$$
\begin{gathered}
\mathrm{E}\left(\mathrm{r}_{\mathrm{i}}\right)=\delta_{0}+\beta_{\mathrm{i} 1} \delta_{1}+\cdots+\beta_{\mathrm{ij}} \delta_{\mathrm{j}}+\beta_{\mathrm{iM}}^{*} \delta_{\mathrm{M}}^{*} ; \\
\delta_{\mathrm{j}}=\left(\mathrm{f}_{\mathrm{j}}-\delta_{0}\right) \text { and } \delta_{\mathrm{M}}^{*}>0
\end{gathered}
$$

Equation (... 35) states that

1. When some factors are dropped, an assets' expected return remains a linear function of the estimated betas of the factors used and the market residual beta.

2. As the number of factors in the model increases, the market residual risk premium approaches a constant value, $\delta_{\mathrm{M}}$.

3. If all factors are excluded, i.e. $\mathrm{j}=0$, the pricing relationship collapses to the CAPM; if all factors are used, i.e. $\mathrm{j}=\mathrm{k}$, then the relationship expands to either Ross infinite APT or unified APT in a finite economy.

4. As the number of excluded factors increases, the role of the market portfolio increases. Rearranging (... 35) gives,

$$
\beta_{\mathrm{iM}}^{*} \delta_{\mathrm{M}}^{*}=\beta_{\mathrm{ij}+1} \delta_{\mathrm{j}+1}+\cdots+\beta_{\mathrm{ik}} \delta_{\mathrm{k}}+\beta_{\mathrm{iM}} \delta_{\mathrm{M}} \text {, }
$$

or

$$
\delta_{\mathrm{M}}^{*}=\frac{\beta_{\mathrm{ij}+1} \delta_{\mathrm{j}+1}+\cdots+\beta_{\mathrm{ik}} \delta_{\mathrm{k}}+\beta_{\mathrm{iM}} \delta_{\mathrm{M}}}{\beta_{\mathrm{iM}}^{*}}
$$

where $\delta_{\mathrm{k}}=\left(\mathrm{f}_{\mathrm{k}}-\delta_{0}\right)$ and $\beta_{\mathrm{iM}}^{*}$ is constant. The addition of factors to (... 36) will have an increasing effect on $\delta_{\mathrm{M}}^{*}$. Wei (1988) states that, in the presence of factor independence, $\varepsilon_{\mathrm{i}}$ and $\varepsilon_{\mathrm{M}}$ act as hidden factors.

\section{Number of Factors in a Model}

Fama (1996) uses the ITCAPM to identify the number of factors that are sufficient to explain returns in the cross-section of stocks. In the ITCAPM, the optimal portfolios for maximizing life-time consumption utility are multifactor-minimum-variance (MMV) portfolios. An 
MMV portfolio carries minimum variance at a given level of expected return and a given level of covariance of returns with state variables, such that

$$
\begin{gathered}
\min \sigma_{p}^{2}=\sum_{i=1}^{n} \sum_{j=1}^{n} w_{i} w_{j} \sigma_{i j}, \quad \text { subject to, } \\
\sum_{\substack{i=1 \\
n}}^{n} w_{i} b_{i s}=b_{p s}, \quad s=1, \ldots, S, \\
\sum_{\substack{i=1 \\
n}}^{n} w_{i} E\left(r_{i}\right)=E\left(r_{p}\right), \\
\sum_{i=1}^{n} w_{i}=1
\end{gathered}
$$

where $\sigma_{\mathrm{p}}^{2}$ is the portfolio variance, $\sigma_{\mathrm{ij}}$ is the covariance among stocks in the portfolio, $\mathrm{b}_{\mathrm{ps}}$ are the loadings of the state variables on the portfolio, $\mathrm{E}\left(\mathrm{r}_{\mathrm{p}}\right)$ is the expected return on the portfolio, and $\mathrm{w}_{\mathrm{i}}$ represents the weights of stock $\mathrm{i}$ in the portfolio.

Fama applies the Lagrange multiplier to (... 37) and differentiates it with respect to $w_{i}$ to determine the the weight of each stock i if there is more than one stock in the MMV portfolio:

$$
w_{i}=\sum_{s=1}^{s} \lambda_{s}\left(\sum_{j=1}^{n} v_{i j} b_{j s}\right)+\lambda_{s+1}\left(\sum_{j=1}^{n} v_{i j} E\left(r_{j}\right)\right)+\lambda_{s+2}\left(\sum_{j=1}^{n} v_{i j}\right)
$$

where $v_{i j}$ is the inverse of the covariance matrix of the stocks, and the $\lambda s$ are the Lagrange multipliers. For every MMV portfolio, the bracketed terms in (... 38) are the same. Fama rescaled the bracketed terms of the state variables so as to convert them into weights for securities in state variables, which are equal to one. This rescaling is necessary to show that there are S+2 MMV portfolios, The new weights are

$$
\begin{gathered}
w_{i s}=\sum_{j=1}^{n} d_{i j} b_{j s} / \sum_{i=1}^{n} \sum_{j=1}^{n} d_{i j} b_{j s} \\
w_{i, s+1}=\sum_{j=1}^{n} d_{i j} E\left(r_{j}\right) / \sum_{i=1}^{n} \sum_{j=1}^{n} d_{i j} E\left(r_{j}\right) \\
w_{i, s+2}=\sum_{j=1}^{n} d_{i j} b_{j s} / \sum_{i=1}^{n} \sum_{j=1}^{n} d_{i j}
\end{gathered}
$$

To reproduce the weights for securities in MMV portfolio p given by (... 38), Fama scales the Lagrange multiplier in (... 38) with the denominator in (... 39):

$$
\begin{array}{r}
\mathrm{q}_{\mathrm{s}}=\lambda_{\mathrm{s}}\left(\sum_{\mathrm{i}=1}^{\mathrm{n}} \sum_{\mathrm{j}=1}^{\mathrm{n}} \mathrm{d}_{\mathrm{ij}} \mathrm{b}_{\mathrm{js}}\right) \\
\mathrm{q}_{\mathrm{s}+1}=\lambda_{\mathrm{s}+1}\left(\sum_{\mathrm{i}=1}^{\mathrm{n}} \sum_{\mathrm{j}=1}^{\mathrm{n}} \mathrm{d}_{\mathrm{ij}} \mathrm{E}\left(\mathrm{r}_{\mathrm{j}}\right)\right) \\
\mathrm{q}_{\mathrm{s}+2}=\lambda_{\mathrm{s}+2}\left(\sum_{\mathrm{i}=1}^{\mathrm{n}} \sum_{\mathrm{j}=1}^{\mathrm{n}} \mathrm{d}_{\mathrm{ij}}\right)
\end{array}
$$

Substituting for $\mathrm{w}_{\mathrm{i}}$ in

$$
\mathrm{w}_{\mathrm{i}}=\sum_{\mathrm{s}=1}^{\mathrm{S}+2} \mathrm{w}_{\mathrm{is}} \mathrm{q}_{\mathrm{s}}
$$

gives

$$
r_{p}=\sum_{i=1}^{n} w_{i} r_{i}
$$

$$
\begin{gathered}
\mathrm{r}_{\mathrm{p}}=\sum_{\mathrm{i}=1}^{\mathrm{n}}\left(\sum_{\mathrm{s}=1}^{\mathrm{s}+2} \mathrm{w}_{\mathrm{is}} \mathrm{q}_{\mathrm{s}}\right) \mathrm{r}_{\mathrm{i}} \equiv \sum_{\mathrm{s}=1}^{\mathrm{s}+2} \mathrm{q}_{\mathrm{s}}\left(\sum_{\mathrm{i}=1}^{\mathrm{n}} \mathrm{w}_{\mathrm{is}} \mathrm{r}_{\mathrm{i}}\right) \\
=\sum_{\mathrm{s}=1}^{\mathrm{S}+2} \mathrm{q}_{\mathrm{s}} \mathrm{r}_{\mathrm{s}}
\end{gathered}
$$

Fama explains the results by saying that the portfolio returns are defined by the weights of securities in state variables (in ... 38) and scaled Lagrange multipliers (in ... 40). Also, the weights of the securities in the MMV portfolio p sum to 1 and, as per (... 39), the weights of the securities in the state variables also sum to 1 . It follows that the weights, $\mathrm{q}_{\mathrm{s}}$, should sum to 1 in order for (... 41) to be solved. As (... 41) applies to all MMV portfolio, it can be deduced that any MMV portfolio is a combination of $\mathrm{S}+2$ portfolios in (... 38). Fama makes two 
relevant propositions: (1) All S+2 portfolios in (... 38) are MMV portfolios; together, they constitute the spanning set of portfolios. (2) The MMV portfolios are linearly independent spanning or basis portfolios, from which any MMV portfolio can be created.

Fama states that, in the presence of risk-free lending and borrowing, (.. 41) transforms into

$$
r_{p}=\sum_{s=1}^{s} q_{s} r_{s}+q_{T} r_{T}+\left[1-\sum_{s=1}^{s} q_{s}-q_{T}\right] r_{f}
$$

In (... 42), $\mathrm{r}_{\mathrm{f}}$, the risk-free rate, replaces the MMV portfolio, $\mathrm{S}+2$, and $\mathrm{T}$, the tangency portfolio of the line drawn from the risk-free rate to the efficient frontier, replaces $\mathrm{S}+1$, the tangency portfolio in (... 39).

In $S+2,+2$ represents two factors in the multifactor relationship that are not state variables: first, a zero-beta portfolio or risk-free asset that is insulated from the fluctuations in the economy (Black, 1972; Fama, 1996; Sharpe, 1964); second, a tangency market portfolio that captures the variations in expected returns independent of the state variables, namely the residual variance of the-MVE-mimicking portfolios. Fama asserts that treating it as a state variable will obscure its economic role.

The preceding models establish the importance of the different types of factors in explaining returns on capital assets, but, with the exception of the CAPM, the models do not actually specify the factors. Chen et al. (1986) propose an economic asset pricing model, which is built on the premise that comovement of asset prices is suggestive of the presence of underlying exogenous economic variables; the stock markets are affected by "general economic state variables" (p. 384). They argue that stock market returns are affected by all variables that have a bearing on an economy's price operators or that dictate dividend payout decisions, and any variable that completes the description of the state of nature should be taken as a systematic risk factor. They propose the following model:

$$
r_{i}=\beta_{0}+\beta_{1} \mathrm{MP}+\beta_{2} \mathrm{DEI}+\beta_{3} \mathrm{UI}+\beta_{4} \mathrm{UPR}+\beta_{5} \mathrm{UTS}+\varepsilon_{\mathrm{i}}
$$

where MP represents the monthly production index, DEI the change in expected inflation, UI the unexpected inflation, UPR the risk premium, and UTS the term structure. MP, DEI, UI, UPR, and UTS are state variables and the $\beta$ s their loadings.

In addition to the variables in (... 43), Chen et al. examine the impact of yearly production, the market portfolio, consumption, and oil prices on stock returns. They drop these factors from the model due to their lack of significance in explaining the stock returns. Using the CAPM as the null model, they test the significance of their model over the period from January 1953 to November 1983 with breaks at January 1973 and December 1977. Besides the variables in (... 43), the value-weighted market portfolio is found to be significant over the whole sample period, although it is only significant in one sub-period; similar behaviour of the market portfolio is observed in the null model.

\section{Fama and French Model}

Asset pricing studies subsequent to the introduction of the CAPM report that, in addition to the market portfolio, there are other factors that affect stock returns in the US market. The factors include size (Banz, 1981), the book to market value of equity (B/M) (Rosenberg et al., 1985; Stattman, 1980), the earnings to price ratio (E/P) (Ball, 1978; Basu, 1983), and the leverage ratio (Bhandari, 1988). Fama and French conduct a series of studies combining these factors in asset pricing models. Using data from 1941 to 1990, Fama and French (1992) perform cross-sectional analysis of the impact of market beta, size, B/M, leverage, and E/P on stock returns. They report that size and B/M subsume the effects of the other factors and are sufficient to explain stock returns. They attribute the redundancy of the other factors to their being scaled versions of stock prices. In the succeeding study, Fama and French (1993) conduct time-series analysis of the data used in the 1992 study using the market portfolio and two mimicking portfolios that proxy for the risks associated with size and the B/M as explanatory factors. The mimicking portfolios are small minus big (SMB) and high minus low (HML), which are created from the intersection of a double sort of firms on size and B/M; the size sort divides firms into two groups using the median and the B/M sort divides each size group into three groups. SMB is the difference between the average returns on the three small-sized portfolios and the three large-sized portfolios, while HML is the difference between the average returns on the two high- $\mathrm{B} / \mathrm{M}$ portfolios and the two low-B/M portfolios. The proposed model is popularly known as the Fama and French three-factor model (FF3F) and takes the form

$$
r_{i t}-r_{f t}=\beta_{0}+\beta_{1}\left(r_{M t}-r_{f t}\right)+\beta_{2} S M B B_{t}+\beta_{3} H_{M L}+\varepsilon_{i t}
$$

where $r_{i t}$ is the return on asset $i$ at time $t, r_{\mathrm{Mt}}$ is the return on the market portfolio at time $t$, and $r_{\mathrm{ft}}$ is the risk-free rate at time $t$. Fama and French (1995) offer an economic rationale for modelling size and B/M based on a study of the impact of changes in those variables on three representations of returns, namely sales, net earnings plus interest and preferred dividends, and the return on equity, using the following model:

$$
\Delta \mathrm{y}_{\mathrm{t}+1}=\beta_{0}+\beta_{1} \Delta \mathrm{M}_{\mathrm{t}+1}+\beta_{2} \Delta \mathrm{SMB}_{\mathrm{t}+1}+\beta_{3} \Delta \mathrm{HML}_{\mathrm{t}+1}
$$

where $\Delta \mathrm{y}_{\mathrm{t}+1}$ is the change in the fundamental variable, and $\Delta \mathrm{M}, \Delta \mathrm{SMB}$, and $\Delta \mathrm{HML}$ represent changes in the market, size and $\mathrm{B} / \mathrm{M}$, respectively. The authors report the relevance of the market and size only, and ascribe the failure of $\mathrm{B} / \mathrm{M}$ to explain returns to the presence of white noise due to a small sample size. The data used cover 1963 to 1992.

Fama and French contend that the three-factor model is a parsimonious model that is capable of capturing the effects of E/P and leverage (Fama and French, 1993), and the cash flow to price ratio, sales rank and long-term past returns (Fama and French, 1996). They conclude that the FF3F is a three-factor version of Merton's (1973) intertemporal model, wherein size and B/M are two state variables of hedging concern to investors.

\section{Characteristic Model}

Lakonishok et al. (1994) argue that the premia associated with SMB and HML are too large for their low covariance with macroeconomic factors, which casts doubt on their ability to explain economy-relevant aggregate risk. Furthermore, Daniel and Titman (1997) assert that stock returns are driven by firm characteristics and not the factor loadings of the characteristics. Assuming an invariant variance-covariance matrix of returns, they propose a characteristic model, which states that

$$
r_{i t}=E\left(r_{i t}\right)+\sum_{k=1}^{K} \beta_{i f} f_{k t}+\varepsilon_{i t}
$$




$$
\mathrm{E}\left(\mathrm{r}_{\mathrm{it}}\right)=\mathrm{a}+\mathrm{b}_{1} \theta_{\mathrm{i}, \mathrm{t}-1}
$$

where $r_{i t}$ is the return on asset $i$ at time $t, f_{k t}$ is the return on factor $k$ at time $t$, and $\theta$ represents the loadings on the distress factors] in the null model. In the characteristic model, innovations in $\theta$ are negatively correlated with the returns on the stock, but $\theta$ is not directly related to the loadings on the distress factorsThe uniqueness of the characteristic model lies in its allowing non-distressed firms to load on the distress factors. Such firms exhibit low $\theta$ commensurate with low returns.

Daniel and Titman test the characteristic model in US markets using monthly data from July 1963 to December 1993 and do not find proof of a separate distress factor. They conclude that the factor loadings do not explain the high returns associated with small-sized and high-B/M stocks beyond the extent to which they act as proxies for these characteristics. In addition, they find that the market beta has no explanatory power for returns after controlling for size and B/M. Factor loadings measured with respect to various macro factors also fail to explain stock returns once characteristics are taken into consideration.

\section{Carhart Model}

Carhart (1997) extends FF3F by introducing Jegadeesh and Titman's (1993) anomaly of one-year momentum in stock returns, the effect of which was not captured by Fama and French (1996), as a fourth factor. He proposes the following four-factor model:

$$
r_{i t}-r_{f t}=\beta_{0 t}+\beta_{1 i t}\left(r_{M t}-r_{f t}\right)+\beta_{2 i t} S B_{t}+\beta_{3 i t} H_{M L}+\beta_{4 i t} P{ } 1 Y R_{t}+\varepsilon_{i t}
$$

where PR1YR represents the return on the mimicking portfolio for the one-year momentum in stock returns. Using data from January 1962 to December 1993he observes that PR1YR funds yield an annual return of 8 percent. The intercept and adjusted $\mathrm{R}^{2}$ results indicate the higher explanatory power of the four-factor model. In addition to PR1YR, Carhart uses three-year past persistent earnings as the fourth factor. Their spread is lower than that of one-year earnings and has comparatively lower explanatory power.

\section{Pastor and Stambaugh Model}

Pastor and Stambaugh (2003) observe remarkable fluctuations in market-wide liquidity during major economic and financial events. In addition, they notice a flight-to-quality effect in the form of investors shifting their investments from stocks to bonds during large liquidity drops. They read these observations as inklings of liquidity being a state variable and incorporate it as a factor in the FF3F and FF3F plus momentum models as follows:

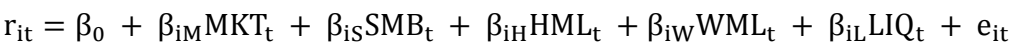

where WML and LIQ represent long-short spreads on the momentum portfolio and the liquidity portfolio, respectively.

To test whether liquidity is a priced factor, they create portfolios of stocks with diverse liquidity betas. They obtain the liquidity betas from the stocks' linear relationship with seven observable variables: the historical beta, average liquidity, average volume, cumulative return, return volatility, price, and shares outstanding:

$$
\beta_{\mathrm{iL}, \mathrm{t}}=\mu_{1, \mathrm{t}}+\mu_{2, \mathrm{t}}^{\prime} \mathrm{Z}_{\mathrm{i}, \mathrm{t}-1}
$$

where $\mathrm{Z}_{\mathrm{i}, \mathrm{t}-1}$ is the vector of the aforementioned seven characteristics and $\mu_{2, \mathrm{t}}$ is a vector of coefficients. The empirical tests of the model in US stock markets using data from August 1962 to December 1999 show significant systematic differences in the intercepts of the portfolio created by the beta sort, testifying that the market-wide liquidity risk is priced in the stock returns.

\section{Francis, LaFond, Olsson, and Schipper's Model}

Francis et al. (2005) state that earnings constitute the primary source of information for investors. The likelihood of the poor quality of earnings reflects the information risk borne by the investors. It is non-diversifiable and must be priced in equilibrium asset pricing models. They argue that the quality of earnings, hence information risk, relates to the quality of accruals in the earnings. They incorporate accrual quality or quality of earnings as a fourth factor along with the three factors of FF3F:

$$
r_{i t}-r_{f t}=\beta_{0 t}+\beta_{1 i t}\left(r_{M t}-r_{f t}\right)+\beta_{2 i t} S M B B_{t}+\beta_{3 i t} H M L_{t}+\beta_{4 i t} A Q_{t}+\varepsilon_{i t}
$$

where $A Q$ denotes the accrual quality. They use an accrual quality metric that is a linear function of current, lagging and leading cash flows, plant, property and equipment (PPE) and change in revenue. To test the model, they use data from US markets over the period from 1970 to 2001 and find that the accrual-quality-mimicking portfolio not only overlaps with the other three factors but also enhances the explanatory power of the model. They conclude that the overlapping effect of accrual quality on size, in particular, indicates that its omission will result in model misspecification.

\section{International Asset Pricing Models}

The growth of stock markets in developed markets outside the US in the early 1970s, together with a decrease in the share of the US market in the world market capitalization, triggered a need for internationally compatible asset pricing models. Solnik (1974) argues that the extension of asset pricing models through the mere addition of foreign investment opportunities will cause the loss of the economic substance and appeal of the models. This subsection reviews the major contributions to the literature on international asset pricing modelling.

\section{Solnik's Model}

Solnik (1974) contends that the basic aspect of international markets is the presence of exchange rate risk and the mechanism devised to compensate investors for bearing this risk. He proposes an international capital asset pricing model (ICAPM) that assumes (1) the presence of perfect capital markets that are always in equilibrium and wherein investors are allowed to short sell securities, (2) continuous trading of assets and the exchange rate and zero correlation between the exchange rate and market returns, (3) homogeneous expectations of investors about exchange rates and the distribution of returns with respect to the asset currency, (4) unconstrained capital flow among international 
markets, and (5) the confinement of investors' consumption to their home countries, with the consumption set not assumed to be uniform across countries. Assumption 4 is the core assumption of the model.

To develop a market-clearing equilibrium ICAPM, Solnik uses the demand function for individual investor k and sums over all investors to obtain the demand function for stocks in country 1 :

$$
d_{l}^{k}=\frac{W^{k}}{A^{k}} \sum_{l=1}^{L} v_{l j}\left(r_{M}-r_{f}\right)
$$

where $d_{1}^{k}$ is the demand for stock in country 1 from investor $\mathrm{k}, \mathrm{W}^{\mathrm{K}}$ represents the wealth of investor $\mathrm{k}, \mathrm{A}^{\mathrm{k}}$ denotes the risk aversion of investor $\mathrm{k}, \mathrm{r}_{\mathrm{M}}$ is the return on market $1, \mathrm{r}_{\mathrm{f}}$ is the risk-free rate in country 1 , and $\mathrm{v}_{\mathrm{lj}}$ is the inverse of the covariance of the returns on assets in country 1 and country $\mathrm{j}$.

Aggregating (... 50) for all investors in country 1 yields

$$
\mathrm{D}_{\mathrm{l}}=\sum_{\mathrm{l}} \mathrm{d}_{\mathrm{l}}^{\mathrm{k}}=\frac{1}{\mathrm{~A}} \sum_{\mathrm{l}=1}^{\mathrm{L}} \mathrm{v}_{\mathrm{lj}}\left(\mathrm{r}_{\mathrm{M}}-\mathrm{r}_{\mathrm{f}}\right)
$$

where $\mathrm{D}_{1}$ denotes the demand for stocks in market 1 , and $\frac{1}{\mathrm{~A}}=\sum_{\mathrm{l}} \frac{\mathrm{W}^{\mathrm{k}}}{\mathrm{A}^{\mathrm{k}}}$ represents the risk tolerance of the investors. Let the weight of the market of country 1 in the world market be $\mathrm{z}_{1}$ and $\mathrm{D}_{1}=\mathrm{z}_{l} \mathrm{G}$, where $\mathrm{G}$ is the value of the world market. Then, (... 51) transforms into

$r_{M}-r_{f}=z_{l} G A \sum_{l=1}^{L} \sigma_{l j}$

In $(\ldots 52), \sum_{\mathrm{l}=1}^{\mathrm{L}} \sigma_{\mathrm{lj}}=\sigma_{\mathrm{lG}}$, hence

$$
r_{M}-r_{f}=z_{l} G A \sigma_{l G}
$$

which, when divided by $z_{l}$, gives

$$
\mathrm{r}_{\mathrm{G}}-\mathrm{r}_{\mathrm{fG}}=\mathrm{GA} \sum_{\mathrm{l}=1}^{\mathrm{L}} \sigma_{\mathrm{lG}}=\mathrm{GA} \sigma_{\mathrm{G}}^{2}
$$

Substituting the value of GA from (... 54) into (... 53) yields the ICAPM of the form

$$
r_{M}-r_{f}=\frac{\sigma_{l G}}{\sigma_{G}^{2}}\left(r_{G}-r_{f G}\right)
$$

Since $\frac{\sigma_{\mathrm{lG}}}{\sigma_{\mathrm{G}}^{2}}=\beta_{\mathrm{IG}},(\ldots 55)$ can be rewritten as

$$
r_{\mathrm{M}}-\mathrm{r}_{\mathrm{f}}=\beta_{\mathrm{IG}}\left(\mathrm{r}_{\mathrm{G}}-\mathrm{r}_{\mathrm{fG}}\right)
$$

Equation (... 56) represents the Solnik (1974) model, which states that the excess return on a stock in country 1 equals the excess return on the global market, over the average global risk-free rate, $\mathrm{r}_{\mathrm{fG}}$, times the ratio of the covariance between the stock return in country 1 and the return on the global market to the variance of the returns in the global market, or $\beta_{\mathrm{lG}}$. In (... 56), the risk-free assets of different countries play different roles. A risk-free asset in a country is the pure exchange rate risk asset for investors from other countries. The investors can hedge their foreign exchange exposure by going short in the foreign bond, $\mathrm{r}_{\mathrm{fG}}$. Consequently, the risk premium has to be independent of the expected changes in parities or inflation. Solnik's model differs from the CAPM (1) in terms of the systematic risk, since it uses global systematic risk, and (2) in that $\mathrm{r}_{\mathrm{f}}$ and $\mathrm{r}_{\mathrm{fG}}$ are expected to be different.

\section{Sercu's Model}

Sercu (1980) relaxes Solnik's (1974) model's assumption of zero correlation between asset returns and exchange rate. Assuming non-zero covariance between asset returns and exchange rate, he decomposes the covariance matrix of the internationally diversifiable portfolio as follows:

$$
\Omega_{\mathrm{ip}}=\left[\begin{array}{cc}
\Omega_{\mathrm{S}} & \Omega_{\mathrm{SX}} \\
\Omega_{\mathrm{SX}}^{\prime} & \Omega_{\mathrm{X}}
\end{array}\right]
$$

where $\Omega_{\mathrm{ip}}$ is the covariance matrix for an internationally diversifiable portfolio, $\Omega_{\mathrm{S}}$ is the covariance matrix of $\mathrm{n}$ risky assets, $\Omega_{\mathrm{X}}$ is the covariance matrix of $L$ exchange rate changes, and $\Omega_{\mathrm{SX}}$ is the matrix of the covariance of the stock returns with exchange rate changes.

Sercu decomposes the excess return on the internationally diversified portfolio into the return on the risky asset portfolio and the return on the foreign bond portfolio:

$$
\left[r_{i}-r_{f}\right]_{n}-[\tau]^{\prime}\left[r_{l}+\psi_{l}-r_{f}\right]=\frac{G}{W} A \sigma_{i, G \mid X}=\frac{G}{W} A \Omega_{S \mid X} W_{i}
$$

where $\left[r_{i}-r_{f}\right]_{n}$ is the vector of excess returns on $n$ common stocks, and $\left[r_{l}+\psi_{l}-r_{f}\right]$ is the vector of excess returns on $L$ foreign bonds, $r_{l}$ is the risk-free rate on the bond in country 1 and $\psi_{1}$ is the exchange rate with the currency of country 1 . G represents the value of the global market, $\mathrm{W}$ represents the world aggregate wealth, and A equals the world mean risk aversion. $\tau$ denotes the exchange rate regression coefficients or foreign bond returns, $\sigma_{\mathrm{i}, \mathrm{G} \mid \mathrm{X}}$ is the covariance of stock i's returns with the return on the global market portfolio, conditional on the exchange rates, and $\Omega_{\mathrm{S} \mid \mathrm{X}}$ is the covariance matrix of the disturbance in stock returns conditional on the exchange rates.

From (... 57), it follows that the expected excess return on a hedged stock is linearly related to its marginal contribution to the risk of the variance in the global market. Given that the exposure of the global market to currency risk, $\tau_{\mathrm{Gl}}=\sum_{\mathrm{l}=1}^{\mathrm{L}} \tau_{\mathrm{jl}} \mathrm{w}_{\mathrm{j}}$, i.e. the value-weighted mean of the exposure of individual stocks, from (... 57), the price of risk equals

$$
\frac{G}{W} A=\frac{\left(r_{G}-r_{f}\right)-\sum_{l=1}^{L} \gamma_{G l}\left(r_{l}+\psi_{l}-r_{f}\right)}{\sigma_{G \mid X}^{2}}
$$

From (... 58) and (.. 57), the excess return on individual stock $j$ equals 


$$
r_{j}-r_{f}=\sum_{l=1}^{L} \gamma_{j l}\left(r_{l}+\psi_{l}-r_{f}\right)+\frac{\sigma_{j G \mid X}}{\sigma_{G \mid X}^{2}}\left[\left(r_{G}-r_{f}\right)-\sum_{l=1}^{L} \gamma_{G l}\left(r_{l}+\psi_{l}-r_{f}\right)\right]
$$

It follows that the risk premium has two components: (1) the cost of the hedge and (2) the CAPM-like premium for the uncertainty independent of the exchange rate, $\frac{\sigma_{\mathrm{GG} \mid \mathrm{X}}}{\sigma_{\mathrm{G} \mid \mathrm{X}}^{2}}$.

\section{Stulz's Model}

Stulz (1984) states that, in integrated global markets, returns on individual assets and individual countries can be obtained from a version of the CAPM that assumes the existence of a well-diversified global market portfolio. The model assumes the following: (1) consumption and opportunity sets are uniform across countries; (2) there exists a single consumption good that is consumed by all investors in all countries; (3) the law of single price holds in real terms, i.e., the consumption parity price (CPP) prevails; (4) all markets are "perfect and frictionless" without any barricades to international investment; (5) the investors are risk averse; (6) the investors can lend and borrow at a given real rate in units of the consumption good.

The return on an individual asset in the global market is given by

$$
E\left(r_{i G}\right)=r_{f}+\beta_{i G}\left[E\left(r_{G}\right)-r_{f}\right]
$$

where $r_{i G}$ is the return on asset $i$ in the global market, $r_{G}$ is the return on the global market portfolio, and $\beta_{i G}$ is the global beta of asset $i$. The return on a market in the global market equals

$$
E\left(r_{M}\right)=r_{f}+\beta_{M G}\left[E\left(r_{G}\right)-r_{f}\right]
$$

where $r_{M}$ is the return on the local market portfolio and $\beta_{M G}$ is the global beta of the local market portfolio. Substituting (... 61) into the local CAPM yields:

$$
E\left(r_{i G M}\right)=r_{f}+\beta_{i M} \beta_{M G}\left[E\left(r_{G}\right)-r_{f}\right]
$$

where $r_{i G M}$ is the return on $i$ under the local CAPM in globally integrated markets. (... 62) allows the impact of global markets on the return on asset $i$ to occur through the effect of the global market on the risk premium of the local market and not through its beta. It follows that $r_{i G}$ can be equal to $\mathrm{r}_{\mathrm{iGM}}$ only if the difference between $\beta_{\mathrm{iG}}$ and $\beta_{\mathrm{iM}} \beta_{\mathrm{MG}}$ is zero.

Assuming commodity price parity, Stulz proposes the following ICAPM in real terms:

$$
\mathrm{E}\left(\mathrm{r}_{\mathrm{i}}^{\mathrm{c}}\right)=\mathrm{r}_{\mathrm{f}}^{\mathrm{c}}+\beta_{\mathrm{G}}^{\mathrm{c}}\left[\mathrm{E}\left(\mathrm{r}_{\mathrm{G}}^{\mathrm{c}}\right)-\mathrm{r}_{\mathrm{f}}^{\mathrm{c}}\right] ; \quad \beta_{\mathrm{G}}^{\mathrm{c}}=\frac{\operatorname{cov}\left(\mathrm{r}_{\mathrm{i}}^{\mathrm{c}}, \mathrm{r}_{\mathrm{G}}^{\mathrm{c}}\right)}{\operatorname{var}\left(\mathrm{r}_{\mathrm{G}}^{\mathrm{c}}\right)}
$$

where $r_{i}^{c}$ is the one-period real return on the ith asset, $r_{G}^{c}$ is the excess real return on the global market portfolio, $r_{f}^{c}$ is the risk-free rate, and $\beta_{G}^{c}$ is the sensitivity of real returns on asset $i$ to returns on the global market portfolio. Superscript c denotes that the units are consumption goods.

The investment set, according to the model, consists of a risk-free asset and a risky global market portfolio. The assumption of the homogeneity of investor expectations across countries, in tandem with the assumption of lending and borrowing at the real rate, renders the existence of multiple countries irrelevant.

\section{The Adler and Dumas Model}

Adler and Dumas (1983) opine that distinguishing domestic markets from international markets requires an economic concept of nationhood. They develop a mean-variance ICAPM that recognizes nations as regions with different purchasing power indices. They argue that all CAPM investors hold optimal portfolios and that market equilibrium is established by the interaction among the required returns on the various assets. They assume a world of $\mathrm{L}+1$ countries in which $\mathrm{N}$ securities are traded. The expected nominal return demanded by investors for holding securities in their portfolios is given by

$$
r_{i}=r_{f}+\sigma_{i \pi}^{l}+\left(1 / A^{k}\right) \sum_{j=1}^{N+1} w_{j}^{l}\left(\sigma_{i j}-\sigma_{i \pi}^{l}\right) ; \quad i=1,2, \cdots, N
$$

where $w_{j}^{1}$ represents the portfolio weight assigned to asset $\mathrm{j}$ in country 1 , and (1/A) represents the investor's risk tolerance. $\sigma_{\mathrm{ij}}$ is the covariance of returns on asset $i$ with returns on asset $j$ and $\sigma_{i \pi}^{l}$ is the covariance of returns on asset $i$ with the rate of inflation in country 1 . The difference, $\left(\sigma_{\mathrm{ij}}-\sigma_{\mathrm{i} \pi}^{\mathrm{l}}\right)$, represents the covariance between the nominal return on $\mathrm{i}$ and the real return on $\mathrm{j}$, the summation of which denotes the covariance of the nominal return on i with the real return on the portfolio of the investor.

(... 64) states that the excess nominal return on an asset is composed of two parts:

1. The covariance of the stock return with the inflation rate in country $1, \sigma_{\mathrm{i} \pi}^{l}$. This is not a risk premium because it exists independently of the investors' level of risk aversion (at $1 / \mathrm{A}=0$ ).

2. A premium for the covariance between the nominal return on the security and the return on the real portfolio of the investor. In CAPM parlance, this is the marginal contribution of stock i to the portfolio risk. It implies that the purchasingpower-conscious investors compare the nominal yield on assets in the global markets with the real return on their benchmark portfolio. The difference between nominal and real returns creates the inflation premium.

Adler and Dumas sum up (... 64) over all nations to propose a multi-beta CAPM that is constituted of L+1 covariance terms with inflation and the covariance with the global market portfolio:

$$
\mathrm{r}_{\mathrm{i}}=\mathrm{r}_{\mathrm{f}}+\sum_{\mathrm{l}=1}^{\mathrm{L}} \delta_{\mathrm{l} \pi} \sigma_{\mathrm{i} \pi}+\delta_{\mathrm{G}} \sigma_{\mathrm{iG}}
$$

where $\delta_{\mathrm{l} \pi}$ and $\delta_{\mathrm{G}}$ denote the world prices of exposure to inflation rates and market risk respectively. Assuming constant inflation in the local currency, $\sigma_{\mathrm{i} \pi}$ represents the covariance of the returns on $i$ with the exchange rate between the local currency and that of country 1 . 
Dumas and Solnik's Model

Dumas and Solnik (1995) state that the conditional form of asset price modelling is imperative for avoiding the mistake of ignoring the information available to the investors. They argue that any anticipated shift in that information is likely to affect the relationship between asset returns and state variables. The resulting risk should be compensated for through the addition of premia for risks due to the covariance of asset returns with state variables. In this context, they propose a conditional version of Adler and Dumas' (1983) model. Like Adler and Dumas, their model assumes the existence of $\mathrm{L}+1$ countries, and a set of $\mathrm{m}$ assets (consisting of $\mathrm{n}$ risky equity assets, $\mathrm{L}$ foreign riskless bonds, and a global market portfolio):

$$
\mathrm{E}\left[\mathrm{r}_{\mathrm{it}} \mid \mathrm{I}_{\mathrm{t}-1}\right]=\sum_{\mathrm{l}=1}^{\mathrm{L}} \delta_{\mathrm{i}, \mathrm{t}-1} \operatorname{cov}\left[\mathrm{r}_{\mathrm{it}}, \mathrm{r}_{\mathrm{n}+\mathrm{l}, \mathrm{t}} \mid \mathrm{I}_{\mathrm{t}-1}\right]+\delta_{\mathrm{G}, \mathrm{t}-1} \operatorname{cov}\left[\mathrm{r}_{\mathrm{it}}, \mathrm{r}_{\mathrm{Gt}} \mid \mathrm{I}_{\mathrm{t}-1}\right]
$$

where $\delta_{\mathrm{i}, \mathrm{t}-1}$ and $\delta_{\mathrm{G}, \mathrm{t}-1}$ represent the time-varying world prices of exchange rate risk and global market risk, respectively. (... 66) defines risk as the covariance between the return on asset $i$ and the exchange rate, and the covariance between the return on asset $i$ and the return on the global market portfolio. $\mathrm{I}_{\mathrm{t}-1}$ represents the information set used by investors in choosing their portfolios, which is defined by a vector of state variables, $\mathrm{S}_{\mathrm{t}-1} . \mathrm{S}_{\mathrm{t}-1}$ is a vector of 1 predetermined state variables that encompasses all the information available to the investors. Adler and Dumas assert that the state variables limit the information available to the investors, hence, their strategy set. The $\delta$ s are expected to be nonlinear functions of exogenous variables related to the state of the economy. $\delta_{\mathrm{i}, \mathrm{t}-1}$ represents the inflation premium, but local inflation is assumed to be constant, and the exchange rate change constitutes the stochastic component of the inflation premium.

\section{Sercu and Uppal's Model}

Sercu and Uppal (1995) devise an ICAPM that, besides assuming the existence of a well-diversified global portfolio, recognizes deviations from purchasing power parity (PPP) due to investors' ability to measure returns on assets in relation to yardsticks that are unique in purchasing power indices. They incorporate an exchange rate factor in the ICAPM to account for the risk due to deviations from PPP:

$$
E\left(r_{i}\right)-r_{f}=\beta_{i}\left[E\left(r_{G}-r_{f}\right)\right]+\gamma_{i}\left[X_{l}+r_{l}-r_{f}\right]
$$

where $r_{i}$ is the return on asset $i$ in the domestic currency of country $1, r_{f}$ is the domestic risk-free rate, $r_{1}$ is the risk-free rate in country $1, X_{l}$ is the exchange rate of currency of 1 and $\gamma_{i}$ is the systematic risk in the exchange rate of country l's currency.

Sercu and Uppal assert that the exchange rate term will drop out of the equation if a PPP relationship holds between the investor's domestic country and the country of investment.

\section{Koedijk, Kool, Schotman, and Dijk’s Model}

Koedijk et al. (2002) examine whether local and international asset pricing models yield different estimates of the asset returns. Assuming a universe of L+1 systematic risk factors that consist of a single global market portfolio and L exchange rates, they extend Solnik and Sercu's model to the following:

$$
E\left[r_{i}-r_{f}\right]=E\left[r_{G}-r_{f}\right] \beta_{i 1}+E\left[X+r_{l}-r_{f}\right]^{\prime} \beta_{i 2}
$$

where $r_{i}$ is the return on asset $i, r_{G}$ is the return on the global market, $r_{l}$ is the vector of the nominal risk-free rate in each country 1 (l=1, $2, \ldots, L), r_{f}$ is the risk-free rate in the numeraire (domestic) currency of asset $i, t$ is a vector of ones, $X$ is the vector of nominal exchange rate returns, and $\beta_{\mathrm{i} 1}$ and $\beta_{\mathrm{i} 2}$ are the global market beta and exchange rate beta respectively. The betas are defined as the regression coefficients in

$$
r_{i}=\alpha_{1 i}+\beta_{i G} r_{G}+\beta_{i X} X^{\prime}+\varepsilon_{i}
$$

where $\alpha_{1 \mathrm{i}}=\mathrm{r}_{\mathrm{f}}\left(1-\beta_{\mathrm{i} 1}\right)+\left(\mathrm{r}_{\mathrm{l}}-\mathrm{tr}_{\mathrm{f}}\right)^{\prime} \beta_{\mathrm{i} 2}$ is a constant. Koedijk et al. condense (... 69) into

$$
\mathrm{r}_{\mathrm{i}}=\alpha_{1 \mathrm{i}}+\beta_{\mathrm{i}} \mathrm{Z}^{\prime}+\varepsilon_{\mathrm{i}}
$$

where $\mathrm{Z}^{\prime}=\left(\mathrm{r}_{\mathrm{G}} \mathrm{X}^{\prime}\right)$ is a vector of global instruments. The idiosyncratic risk $\varepsilon_{\mathrm{i}}$ is orthogonal to $\mathrm{Z}$.

Koedijk et al. argue that the ICAPM and CAPM decompose asset risk into systematic and idiosyncratic components differently. The models can be compared only if the return on the local market of a country, $r_{M}$, is related to the vector of global factors $Z$ '. They state that the comparison is then possible because the ICAPM applies to all individual stocks and local markets. It follows that

$$
r_{L}=\alpha_{L}+\beta_{L} Z^{\prime}+\varepsilon_{L}
$$

where $\varepsilon_{L}$ is orthogonal to Z. Substituting $(\ldots 71)$ into the regression representation of the return on the local market $\left(r_{i}=\alpha_{2 i}+\beta_{i} r_{L}+\epsilon_{i}\right)$ gives

$$
\mathrm{r}_{\mathrm{i}}=\alpha_{3 \mathrm{i}}+\beta_{\mathrm{L}} \beta_{\mathrm{i}} \mathrm{Z}^{\prime}+\beta_{\mathrm{i}} \varepsilon_{\mathrm{L}}+\epsilon_{\mathrm{i}}
$$

where $\alpha_{3 \mathrm{i}}=\alpha_{2 \mathrm{i}}+\beta_{\mathrm{i}} \alpha_{\mathrm{L}}$. The authors suggest a simpler way of inserting global factors into the domestic CAPM regression equation,

$$
r_{i}=\alpha_{4 i}+\beta_{i} r_{L}+\lambda_{i} Z^{\prime}+v_{i}
$$

and testing null hypothesis $\mathrm{H}_{0}: \lambda_{\mathrm{i}}=0$. When the null is not rejected, the domestic portfolio reflects all information relevant to asset pricing; in other words, domestically diversifiable risk can be diversified globally. On the contrary, when the null is rejected, use of the domestic CAPM will lead to pricing error as it ignores the risk that is systematic in the global market.

\section{International Arbitrage Pricing Theory}

Solnik (1983) puts forth an international version of APT to explain the cross-sectional variations in international asset returns. APT states that arbitrage portfolios do not carry systematic or unsystematic risks (Ross, 1976). However, exchange rate fluctuations add another risk dimension to internationally diversified portfolios, which makes the extension of APT to the international setting challenging. Therefore, international arbitrage pricing theory (IAPT) requires the following three conditions to be satisfied: (1) exchange risk to be diversifiable, (2) arbitrage portfolios to be risk free across countries, and (3) the factor structure to be immune to the choice of currency. The third condition 
is compulsory for IAPT. IAPT assumes that the asset returns, denominated in local currency, are defined by a k-factor linear model of the form

$$
\mathrm{r}_{\mathrm{i}}^{\mathrm{l}}=\mathrm{E}\left(\mathrm{r}_{\mathrm{i}}^{\mathrm{l}}\right)+\beta_{\mathrm{i} 1}^{\mathrm{l}} \mathrm{f}_{1}+\beta_{\mathrm{i} 2}^{\mathrm{l}} \mathrm{f}_{2}+\cdots+\beta_{\mathrm{ik}}^{\mathrm{l}} \mathrm{f}_{\mathrm{k}}+\varepsilon_{\mathrm{i}}^{\mathrm{l}}
$$

where $r_{i}^{l}$ is the return on asset $i$ in the local currency of country $1, f_{k}(k=1,2, . ., K)$ represent $K$ common factors that affect the return on $i$, and $\beta_{\mathrm{ik}}^{\mathrm{l}}$ is the sensitivity of the return on $\mathrm{i}$, in the local currency, to a change in factor $\mathrm{k}$ in country $1(1=1,2, \ldots, \mathrm{L}) . \varepsilon_{\mathrm{i}}^{\mathrm{l}}$ is the error term. An investor is expected to convert returns on international investments into some reference currency, say his home currency. Assuming a continuous-time change in the exchange rate, the return on any asset $i$, in the domestic currency, can be expressed as

$$
r_{i}^{h}=r_{i}^{l}+X_{l}^{h}+\operatorname{cov}\left(r_{i}^{l}, X_{l}^{h}\right)
$$

Combining (...74) and (...75) gives

$$
\begin{aligned}
\mathrm{r}_{\mathrm{i}}^{\mathrm{h}}= & \mathrm{E}\left(\mathrm{r}_{\mathrm{i}}^{\mathrm{h}}\right)+\beta_{\mathrm{i} 1}^{\mathrm{l}} \mathrm{f}_{1}+\beta_{\mathrm{i} 1}^{\mathrm{l}} \mathrm{f}_{1}+\cdots+\beta_{\mathrm{i} 1}^{\mathrm{l}} \mathrm{f}_{1}+\varepsilon_{\mathrm{i}}^{\mathrm{l}}+\mathrm{u}_{\mathrm{l}}^{\mathrm{h}} \\
& \text { with } \mathrm{E}\left(\mathrm{r}_{\mathrm{i}}^{\mathrm{h}}\right)=\mathrm{E}\left(\mathrm{r}_{\mathrm{i}}^{\mathrm{l}}\right)+\mathrm{E}\left(\mathrm{X}_{\mathrm{l}}^{\mathrm{h}}\right)+\operatorname{cov}\left(\mathrm{r}_{\mathrm{i}}^{\mathrm{l}}, \mathrm{X}_{\mathrm{l}}^{\mathrm{h}}\right)
\end{aligned}
$$

Equation (... 76) incorporates the extra source of risk in the form of exchange rate risk in IAPT. The source of risk is represented by the component of unexpected changes in exchange rates, $\mathrm{u}_{\mathrm{i}}^{\mathrm{h}}$.

Ikeda (1991) contends that the construction of risk-free arbitrage portfolios is difficult as long as exchange rate risk exists. He argues that the expected returns on asset $\mathrm{i}$ ought to be adjusted for the cost of the currency hedge. He modifies IAPT as follows:

$$
\mathrm{E}\left(\mathrm{r}_{\mathrm{i}}^{\mathrm{l}}\right)-\left[\mathrm{r}_{\mathrm{f}}^{\mathrm{l}}+\mathrm{E}\left(\mathrm{X}_{\mathrm{l}}\right)\right]=\delta_{1} \beta_{\mathrm{i} 1}^{\mathrm{l}}+\delta_{2} \beta_{\mathrm{i} 2}^{\mathrm{l}}+\cdots+\delta_{\mathrm{k}} \beta_{\mathrm{ik}}^{\mathrm{l}}
$$

where $\mathrm{r}_{\mathrm{f}}^{\mathrm{l}}$ represents the risk-free rate in country $1, \mathrm{X}_{\mathrm{l}}$ represents the spot exchange rate of currency 1 in the numeraire currency, $\delta_{\mathrm{k}}$ denotes the premium on the "unit exposure of any foreign investment with regards to the kth international source of risk", in the numeraire currency, and $\beta_{\mathrm{ik}}^{\mathrm{l}}$ represents the factor loadings of the corresponding factors in the local currency. $\left[\mathrm{r}_{\mathrm{f}}^{\mathrm{l}}+\mathrm{E}\left(\mathrm{X}_{\mathrm{l}}\right)\right]$ denotes the cost of hedging the foreign exchange risk. On the right hand side of the equation are the prices of the factors, in the numeraire currency, multiplied by the local betas.

\subsection{ASSET PRICING IN EMERGING MARKETS}

Emerging markets are structurally different from developed markets (Pereiro, 2010) and are partially integrated with the global markets (Bekaert and Harvey, 1997). The partial integration of emerging markets undermines the effectiveness of asset pricing models in explaining stock returns in these markets, which necessitates the customization of the models to the local settings (Harvey, 1995). The studies conducted in emerging markets can be broadly categorized into two groups: (1) studies that model the unique characteristics of emerging markets, and (2) studies that apply and test models originally designed for developed markets. The studies in this group primarily focus on modelling the effects of sovereign risk (model 3.1 - 3.3), low market liquidity (model $3.4-3.5$ ), and exchange rate risk (model 3.6 - 3.8) on asset prices in emerging markets.

\section{Godfrey and Espinosa's Model}

Godfrey and Espinosa (1996) argue that political and economic transformations of emerging markets add new dimensions of risk to investing in these markets, in the form of country risk. They propose the following model:

$$
E\left(r_{i l}\right)=r_{f}+\beta_{a}\left[E\left(r_{G}\right)-r_{f}\right]+C R_{l}
$$

where $r_{i l}$ is the return on asset $i$ in country $1, r_{G}$ is the return on the global market, $r_{f}$ is the risk-free asset of the base currency, $\beta_{a}$ represents the adjusted beta, and $\mathrm{CR}_{1}$ denotes the credit risk or spread of the sovereign bond of country l over the US Treasury bond, which represents the dimension of risk specific to the emerging market. The adjusted beta uses the total risk, not just the systematic risk as prescribed by the CAPM. The authors advocate the use of the total risk in the beta calculation because, in many emerging markets, the CAPM betas were found to be less than one, and in many cases were lower than those in developed markets.

\section{Sabal's Model}

Sabal (2004) refutes the use of the sovereign bond spread as a proxy for credit risk for the following reasons: (1) it undermines the differences in the reputations of firms; (2) the addition of a country risk premium indicates that the country risk is fully systematic or non-diversifiable; (3) it measures credit risk, not country risk, and the two are not equivalent. He further argues that the application of the CAPM to emerging markets suffers from the following limitations: (1) high fluctuations in these markets makes it difficult to compute systematic risk with confidence; (2) the illiquidity of these markets makes it difficult to measure historical returns accurately; (3) the high concentration of firms in these markets weakens the ability of the market beta to fully capture systematic risk. He proposes a modified version of Sercu and Uppal's (1995) ICAPM under the condition of PPP. The model attempts to overcome the problem of measuring beta accurately in an emerging market by advocating the computation of the beta as a weighted average of the betas of firms in different markets. The model assumes that the asset returns are related to multiple markets. The model is of the form

$$
E\left(r_{i, l}\right)=r_{f}+\beta_{w}\left[E\left(r_{G}\right)-r_{f}\right]
$$

where $r_{i, l}$ is the return on asset $i$ in country $1, r_{G}$ represents the return on the global market, and $r_{f}$ represents the risk-free rate in the base currency. $\beta_{\mathrm{w}}$ represents the weighted beta,

$$
\begin{gathered}
\beta_{\mathrm{w}}=\mathrm{w}_{\mathrm{M}} \beta_{\mathrm{iM}}+\mathrm{w}_{\mathrm{m}} \beta_{\mathrm{im}}+\mathrm{w}_{\mathrm{n}} \beta_{\mathrm{in}} ; \\
\mathrm{w}_{\mathrm{M}}+\mathrm{w}_{\mathrm{m}}+\mathrm{w}_{\mathrm{n}}=1
\end{gathered}
$$

where $\beta_{\mathrm{iM}}, \beta_{\mathrm{im}}, \beta_{\mathrm{in}}$ represent the standardized covariance between the return on $\mathrm{i}$ and the returns on market $\mathrm{M}$, $\mathrm{m}$ and $\mathrm{n}$, respectively. The weights assigned to the betas depend on the income of firm i originating from each corresponding market. Sabal asserts that the weighted beta is more reliable because it is derived from information on markets that are reliable. 
Grandes, Panigo, and Pasquini’s Model

Grandes et al. (2010) argue that the sovereign spread is systemic in nature and is the main determinant of the default risk of firms in a country. They scale up the pure risk-free rate by the sovereign spread and propose the following model:

$$
r_{i, t}=r_{f, t}+S S_{l, t}+\beta_{i}\left[r_{M, t}-r_{f, t}-S_{l, t}\right]
$$

where $\left[r_{M, t}-r_{f, t}-S S_{l, t}\right]$ is the excess market return adjusted for the sovereign spread in country $1\left(\mathrm{SS}_{\mathrm{l}, \mathrm{t}}\right)$, and $\beta_{\mathrm{i}}$ indicates the sensitivity of the return on asset $i$ to the sovereign spread-adjusted market return.

Grandes et al. test their model in seven Latin American markets using data over the period from 1993 to 2004 . To assess the robustness of their model, they expose it to global and firm-specific factors, which they obtain from Koedijk et al.'s (2002) model and the FF3F, respectively. They report that neither the global market and exchange rate nor the size and value factors are jointly significant.

Bekaert, Harvey, and Lundblad's Model

One of the characteristics of emerging markets is their low market liquidity. To investigate the impact of market liquidity on stock returns, Bekaert et al. (2007) put forth a two-factor model with market portfolio and liquidity as risk factors. They propose the following model:

$$
E\left(r_{i, t}\right)=r_{f, t}-\frac{1}{2} \operatorname{var}_{t}\left(r_{i, t}\right)+\gamma_{G} \operatorname{cov}_{t}\left(r_{i, t}, r_{G, t}\right)+\gamma_{L G} \operatorname{cov}_{t}\left(r_{i, t+i}, L_{G, t}\right)
$$

where $E\left(r_{i, t}\right)$ is the expected return on stock $i$ at time $t, \operatorname{cov}_{t}\left(r_{i, t}, r_{G, t}\right)$ and $\operatorname{cov}_{t}\left(r_{i, t}, L_{G, t}\right)$ represent stock i's covariance with the global market and global liquidity respectively, and $\gamma_{\mathrm{G}}$ and $\gamma_{\mathrm{LG}}$ are the corresponding risk prices. The model is designed for asset pricing under the condition of market integration. They also propose a model for asset pricing under the condition of market segmentation, wherein the stock returns' covariance with the global market is replaced with the variance of the stock returns and stock returns' covariance with global liquidity is replaced with the stock returns' covariance with local liquidity:

$$
E\left(r_{i, t+1}\right)=r_{f, t}-\frac{1}{2} \operatorname{var}_{t}\left(r_{i, t+1}\right)+\gamma_{i} \operatorname{var}_{t}\left(r_{i, t+i}\right)+\gamma_{L i} \operatorname{cov}_{t}\left(r_{i, t+i}, L_{i, t+i}\right)
$$

Bekaert et al. use the monthly value-weighted price pressure as their measure of liquidity:

$$
\mathrm{PP}_{\mathrm{id}}=\frac{\sum_{\mathrm{j}=1}^{\mathrm{n}} \mathrm{w}_{\mathrm{j}} \phi_{\mathrm{j}, \mathrm{d}}\left|\mathrm{r}_{\mathrm{j}, \mathrm{d}, \mathrm{T}}\right|}{\sum_{\mathrm{j}=1}^{\mathrm{n}} \mathrm{w}_{\mathrm{j}}\left|\mathrm{r}_{\mathrm{j}, \mathrm{d}, \mathrm{T}}\right|}
$$

where $P P_{i d}$ is the price pressure in country $i$ on day $d, w_{j}$ is the weight of stock $\mathrm{j}$ in the index, $r_{j, d, T}$ approximates what the expected returns would be if there were trading on the no-trading days, $\mathrm{T}$ stands for the number of no-trading days, and $\phi_{\mathrm{j}, \mathrm{d}}$ represents the no-trading days. They test their model in 19 emerging markets using firm-level data spanning from January 1993 to December 2003 using Hansen and Jagannathan's (1991) distance metric. They report that the segmented model does a better job than the fully integrated model and that the liquidity factor is more important than the market factor in explaining returns in emerging markets.I

\section{Hearn, Piesse, and Strange's Model}

Hearn et al. (2010) argue that illiquidity is not only pervasive but is also a major barrier to investing in emerging markets. To examine the pervasiveness of illiquidity they modify the FF3F by replacing HML with an illiquidity-mimicking portfolio, such that

$$
r_{i}-r_{f}=\alpha_{i}+\beta_{i M}\left(r_{M}-r_{f}\right)+\beta_{i s} S M B+\beta_{i l} \text { ILLIQ }+\varepsilon_{i}
$$

where $\alpha_{i}$ is the Jensen inequality and ILLIQ represents the illiquidity-mimicking portfolio. They adopt Amihud's (2002) procedure for computing illiquidity:

$$
\text { ILLIQ }_{j t} \equiv \frac{1}{D_{j t}} \sum_{d=1}^{D_{j t}} \frac{\left|r_{j d t}\right|}{V O L_{j d t}}
$$

where ILLIQ $\mathrm{j}_{\mathrm{jt}}$ stands for the illiquidity of stock $\mathrm{j}$ in month $\mathrm{t},\left|\mathrm{r}_{\mathrm{jdt}}\right|$ is the absolute return on stock $\mathrm{j}$ on day $\mathrm{d}$ in month $\mathrm{t}, \mathrm{VOL}_{\mathrm{jdt}}$ represents the trading volume of stock $\mathrm{j}$ on day $\mathrm{d}$, and $\mathrm{D}_{\mathrm{jt}}$ represents the number of trading days on which stock $\mathrm{j}$ is traded in month $\mathrm{t}$. The market-wide illiquidity is obtained as the sum of the illiquidity of all the stocks in the market. They test their model in four African countries using data from January 1996 to December 2007 and report that size and illiquidity are persistent and priced, with size having higher explanatory power.

\section{Phylaktis and Ravazzolo's Model}

Phylaktis and Ravazzolo (2004) extend De Santis and Imrohoroglu's (1997) model to examine the impact of foreign exchange risk on equity returns in emerging markets while allowing for the time-varying liberalization of the markets. The model is of the form

$$
\begin{aligned}
r_{i t}=\beta_{0}-X_{i t}+ & \sum_{\mathrm{k}=1}^{\mathrm{p}} \beta_{1 \mathrm{kt}}\left(\mathrm{r}_{\mathrm{i}, \mathrm{t}-\mathrm{k}}+\mathrm{X}_{\mathrm{t}-\mathrm{k}}\right)+\beta_{2 \mathrm{t}} \sigma_{\mathrm{Mt}}^{2} \mathrm{DV} \mathrm{t}+\beta_{3 \mathrm{t}} \sigma_{\mathrm{x}}^{2} \mathrm{DV}_{\mathrm{t}}+2 \beta_{4 \mathrm{t}} \sigma_{\mathrm{Mx}} \mathrm{DV} V_{\mathrm{t}}+\beta_{5 \mathrm{t}} \sigma_{\mathrm{MG}}\left(1-\mathrm{DV}_{\mathrm{t}}\right) \\
& +\beta_{6 \mathrm{t}} \sigma_{\mathrm{xG}}(1-\mathrm{DV} \mathrm{t})+\beta_{7 \mathrm{t}} \sigma_{\mathrm{Mx}}(1-\mathrm{DV} \mathrm{t})+\beta_{8 \mathrm{t}} \sigma_{\mathrm{x}}^{2}\left(1-\mathrm{DV} V_{\mathrm{t}}\right)+\varepsilon_{\mathrm{it}}
\end{aligned}
$$

where $\mathrm{X}_{\mathrm{it}}$ represents changes in the spot exchange rate, $\sigma_{\mathrm{Mt}}^{2}$ the variance of returns on the local market, $\sigma_{\mathrm{x}}^{2}$ the variance of the changes in the spot exchange rate, $\sigma_{\mathrm{Mx}}$ the covariance between returns on the local market and changes in the spot exchange rate, and $\sigma_{\mathrm{xG}}$ the covariance of returns on the global market portfolio and changes in the spot exchange rate. $\mathrm{DV}_{\mathrm{t}}$ is a dummy variable that takes a value of 1 in the preliberalization period and 0 in the post-liberalization period. The model allows positive and negative exchange rate coefficients to reward investors for accepting foreign exchange risk and to account for currency depreciation. The empirical tests of the model in six emerging markets, over the period from 1980 to 2000 , lend support to the inclusion of foreign exchange risk in asset pricing models for emerging markets, as the risk is found to be priced in both the pre- and post-liberalization periods. The authors conclude that excluding foreign exchange risk may lead to the misspecification of the model. 
Carrieri et al. (2006a and 2006b) propose a model for investigating whether local currency risk is priced in the presence of global factors, and whether local currency risk and local market risk are priced separately in emerging markets. The model assumes partial integration of markets and takes the form

$$
\mathrm{E}_{\mathrm{t}-1}\left(\mathrm{r}_{\mathrm{M}, \mathrm{t}}\right)=\delta_{\mathrm{G}, \mathrm{t}-\mathrm{i}} \operatorname{cov}_{\mathrm{t}-\mathrm{i}}\left(\mathrm{r}_{\mathrm{M}, \mathrm{t}}, \mathrm{r}_{\mathrm{G}, \mathrm{t}}\right)+\sum_{\mathrm{l}=1}^{\mathrm{L}} \delta_{\mathrm{l}, \mathrm{t}-1} \operatorname{cov}_{\mathrm{t}-1}\left(\mathrm{r}_{\mathrm{M}, \mathrm{t}}, \pi_{\mathrm{l}, \mathrm{t}}\right)+\delta_{\mathrm{M}, \mathrm{t}-1} \operatorname{var}_{\mathrm{t}-1}\left(\mathrm{r}_{\mathrm{M}, \mathrm{t}}\right)
$$

where $r_{M}$ and $r_{G}$ denote the excess returns on country l's market portfolio and the world market portfolio respectively, $\pi_{l, t}$ represents country l's rate of inflation, the $\delta$ s stand for the prices of the risk factors, and $\mathrm{L}$ denotes the number of countries in the world.

To differentiate between global and local currency risks, the authors divide the currency rate into an index for major currencies and an exchange rate factor for the local currency. The resultant four-factor model is of the form

$$
\begin{gathered}
\mathrm{E}_{\mathrm{t}-1}\left(\mathrm{r}_{\mathrm{M}, \mathrm{t}}\right)=\delta_{\mathrm{G}, \mathrm{t}-\mathrm{i}} \operatorname{cov}_{\mathrm{t}-\mathrm{i}}\left(\mathrm{r}_{\mathrm{M}, \mathrm{t}}, \mathrm{r}_{\mathrm{G}, \mathrm{t}}\right)+\delta_{\mathrm{mx}, \mathrm{t}-1} \operatorname{cov}_{\mathrm{t}-\mathrm{i}}\left(\mathrm{r}_{\mathrm{M}, \mathrm{t}}, \mathrm{e}_{\mathrm{mx}, \mathrm{t}}^{\mathrm{r}}\right)+\delta_{\mathrm{bx}, \mathrm{t}-1} \operatorname{cov}_{\mathrm{t}-1}\left(\mathrm{r}_{\mathrm{M}, \mathrm{t}}, \mathrm{e}_{\mathrm{bxi}, \mathrm{t}}^{\mathrm{r}}\right) \\
+\delta_{\mathrm{M}, \mathrm{t}-1} \operatorname{var}_{\mathrm{t}-1}\left(\mathrm{r}_{\mathrm{M}, \mathrm{t}}\right)
\end{gathered}
$$

where $\mathrm{e}_{\mathrm{mx}, \mathrm{t}}^{\mathrm{r}}$ represents the change in the major currency index, $\mathrm{e}_{\mathrm{bxi}, \mathrm{t}}^{\mathrm{r}}$ represents the change in the local currency, and $\delta_{\mathrm{mx}}$ and $\delta_{\mathrm{ex}}$ are the corresponding risk prices. Tests of the model in seven emerging markets reveal that the risk premia display time-varying behaviour and local market risk contributes more than 50 percent to the overall risk premium. In comparison, the currency risk premium is found to be lower, at about one third of the local market premium.

\section{Harvey's Model}

Harvey (1995) investigates the impact of global economic forces on stock returns in emerging markets. Besides the exchange rate, he uses the return on the global market, global commodity prices (oil prices), global inflation, and the global economic cycle as factors in a fivefactor model of the form

$$
E\left(r_{i}-r_{f}\right)=\beta_{0}+\beta_{1}\left(r_{G}-r_{f}\right)+\beta_{2} X_{i}+\beta_{3} C P_{G}+\beta_{4} \pi_{G}+\beta_{5} E_{G}
$$

where $\mathrm{X}_{\mathrm{i}}$ is the exchange rate of the currency of country $\mathrm{i}$, and $\mathrm{CP}_{\mathrm{G}}, \pi_{\mathrm{G}}$, and $\mathrm{EC}_{\mathrm{G}}$ are the global commodity price, global inflation rate, and global economic cyclerespectively.

Harvey tests the five-factor model against the single-factor ICAPM and a two-factor model to assess whether the inclusion of new factors improves the explanatory power of the model. The two-factor model comprises the global market and the exchange rate. The test results of the models for 20 emerging markets, using data from February 1976 to June 1992, reveal that none of the models explains the stock returns in emerging markets. Harvey asserts that, together, the five factors can be treated as a portfolio and the inability of the factors to explain returns is equivalent to the portfolio being inefficient.

Fama and French's Two-Factor Model

Fama and French (1998) perform a study in the US, 12 EAFE (Europe, Australia, and the Far East) countries, and 16 emerging markets to investigate the pervasiveness of the value premium. They use the CAPM and a two-factor version of the ICAPM to test the explanatory power of B/M in the international markets. The two factors used are the market portfolio and HML. HML is created from the difference in the average returns of high- and low-B/M portfolios. The underlying assumptions of the two-factor model are the integration of global markets and the presence of PPP among nations. The two-factor model takes the form

$$
r_{i}-r_{f}=\alpha_{i}+\beta_{i 1}\left(r_{G}-r_{f}\right)+\beta_{i 2}(H M L)+\varepsilon_{i}
$$

Fama and French observe that, in emerging markets, the CAPM intercepts are not significantly different from zero and the two-factor model has higher explanatory power than the CAPM. They observe that the B/M premium is pervasive. However, due to a small sample and the high volatility of returns in emerging markets they are unable to conclude that the premium is reliably positive. They infer the existence of a size effect in emerging markets as they observe higher returns on small stocks than on big stocks in 11 of the 16 markets. They conclude that their two-factor model, the one-state-variable version of the ITCAPM, is parsimonious in capturing the value premium in portfolios constructed using earnings-to-power ratio, cashflow-to-price ratio, and dividend-to-price ratio sorts.

\section{Barry, Goldreyer, Lockwood, and Rodriguez's Model}

Barry, Goldreyere, Lockwood and Rodriguez (2002) study 35 emerging markets over the 15-year period from 1985 to 2000 to investigate the relevance of size and B/M to stock returns. They combine multiple methods, such as univariate and multivariate tests, parametric and non-parametric tests, and data with and without outliers. They argue that the use of multiple methods testifies to the robustness of the results. In their study, they use the following model:

$$
r_{i}=\gamma_{0}+\gamma_{1} \text { RL_SIZE }+\gamma_{2} \text { RL_B } / M+\gamma_{3} \beta_{M}+\gamma_{4} \beta_{G}+\varepsilon_{i}
$$

where the $\gamma$ s are the regression coefficients, $\beta_{M}$ and $\beta_{G}$ are local and global betas, respectively, RL_SIZE represents relative size, and RL_B/M relative $\mathrm{B} / \mathrm{M}$. The relative size and $\mathrm{B} / \mathrm{M}$ are calculated as actual size and $\mathrm{B} / \mathrm{M}$ values for a stock, divided by the average market value of size and $\mathrm{B} / \mathrm{M}$ respectively. Barry et al. defend the use of relative values, particularly for $\mathrm{B} / \mathrm{M}$, saying that it allows comparison across nations with different accounting standards, whereas normally the different measures used for computing $\mathrm{B} / \mathrm{M}$ in different countries make it incompatible across countries.

Barry et al. observe a robust relationship between B/M and returns. Controlling for size, high-B/M firms earn significantly higher returns than low-B/M firms; the relationship is significant in parametric and non-parametric tests and after the removal of extreme values. In addition, small-sized firms outperform big firms when size is tested independently after controlling for B/M, and in the parametric test. The explanatory 
power of size fades away when non-parametric tests are conducted and outliers excluded. However, they caution against the exclusion of outliers as they occur frequently and influence results in emerging markets.

\section{Empirical Tests of Developed Market Models}

Rouwenhorst (1999) studies 20 emerging markets using monthly data from January 1982 to April 1997 to investigate whether market, size, $\mathrm{B} / \mathrm{M}$, and momentum are priced in these markets. He also examines whether the market liquidity of firms, measured as share turnover, has an indirect impact on the other factors. He finds that small and high-B/M stocks earn higher returns than big and low-B/M stocks, and that there is momentum in the stock returns. However, he does not observe higher returns on high-beta stocks nor does he find a relationship between liquidity and stock returns. He concludes that return factors in emerging markets are qualitatively similar to those in developed markets, but with local character.

Drew and Veeraraghavan $(2002,2003)$ apply the FF3F model to Malaysia, Korea, Hong Kong, and the Philippines, using data from December 1991 to December 1999. They find that all three factors - market portfolio, size, and B/M — are pervasive in all markets. However, the explanatory power of the models is observed to be higher in Malaysia, where the coefficient of determination $\left(\mathrm{R}^{2}\right)$ of the model ranges from 0.87 to 0.93 . The ranges of $\mathrm{R}^{2}$ in Korea, Hong Kong, and the Philippines are found to be [0.74-0.84], [0.57-0.66] and [0.52-0.75], respectively. The intercept is not significantly different from zero for any of the portfolios in any of the markets, except for the big and high$\mathrm{B} / \mathrm{M}$ portfolio in Malaysia.

Jun et al. (2003) test the impact of liquidity on the cross-section of returns in 27 emerging markets using data from January 1992 to December 1999. They use three measures of liquidity, namely the turnover ratio, the trading value, and the turnover-volatility ratio. Consistent with the findings in developed markets, they find a positive correlation between liquidity, including cross-sectional liquidity, and expected returns. They attribute the relationship of cross-sectional liquidity with expected returns to the lower level of integration of emerging markets with the global market.

Dash and Mahakud (2013) examine the explanatory power of three alternative multifactor models in India. The models used are the Fama and French (1993) three-factor, Carhart's (1997) four-factor, and Pastor and Stambaugh's (2003) five-factor models. Using data from September 1995 to March 2011, they study non-financial firms listed on the National Stock Exchange (NSE) of India. They find that the $\mathrm{B} / \mathrm{M}$ factor of the three-factor model is not relevant to returns on large stocks, and the momentum factor of the four-factor model is not significant in the case of winner stocks. The liquidity factor in the five-factor model is significant and priced in the market. The observed adjusted $\mathrm{R}^{2}$ ranges from 0.41 to 0.61 for the three-factor model, from 0.44 to 0.62 for the four-factor model, and from 0.47 to 0.62 for the five-factor model. They conclude that the five-factor model is the most appropriate for pricing assets in the Indian market.

Unlu (2013) conducts a similar study in the Istanbul stock market, in Turkey, over the period from July 1992 to June 2011 . He also finds that the five-factor model has marginally better explanatory power than Carhart's four-factor and Fama and French's three-factor models. The observed ranges of the adjusted $\mathrm{R}^{2}$ for the three-, four- and five-factor models are [0.73-0.87], [0.74-0.87], and [0.75-0.83], respectively.

\subsection{CONCLUSION}

Asset pricing theory came into being with the introduction of the CAPM by Sharpe in 1964. The CAPM is a static, single-period, singlefactor model that assumes that the market portfolio is sufficient to explain the returns of all risky assets. The CAPM further asserts that investors should be rewarded only for bearing systematic risk, represented by the covariance of the return of a risky asset with that of the market portfolio. However, subsequent studies have found that the market beta under- and over-estimates the risk on high- and low-beta portfolios respectively (Jensen et al., 1972) and that there are factors other than the market portfolio that affect stock returns (Ball, 1978; Banz, 1981; Basu, 1983; Bhandari 1988; Rosenberg et al., 1985; Stattman, 1980). Furthermore, investors make investment decisions based on expectations about the returns in the current and future periods, which cannot be modelled by the single-period static CAPM (Merton, 1973). Merton proposes a multi-period, dynamic intertemporal capital asset pricing model that incorporates state variables that affect investors' investment opportunity sets. Ross (1976) asserts that the mean variance efficiency of the market portfolio in the CAPM is contentious and puts forth an alternative to the CAPM in the form of APT. APT assumes that an investment universe consists of finite assets and treats the market portfolio as a mean-zero common factor of no special consequence. APT states that asset returns are driven by multiple mean-zero factors. Connor (1984) relaxes the assumption of infinite assets and Wei (1988) combines APT and the CAPM to obtain an exact asset pricing relationship. Fama (1996) demonstrates that, in a multifactor setting, S+2 variables are required to explain the asset returns; S are state variables, one variable is the market portfolio, and the final variable is the risk-free asset. However, the models do not identify the state variables.

Chen et al. (1986) put forth an economic multifactor model that identifies and uses five factors as the drivers of returns on assets. They argue that an economic variable relates to stock returns only if it has a significant relationship with at least one state variable and that any variable that completes the description of the state of nature of asset prices should be treated as a systematic risk factor. Fama and French $(1992,1993,1996)$ combine the factors found to affect stock returns and arrive at a three-factor model they assume to be parsimonious in capturing the impact of all return-relevant factors. The Fama and French three-factor model has been extended through the incorporation of other factors that are pervasive in stock returns; the factors include momentum (Carhart, 1997), liquidity and momentum (Pastor and Stambaugh, 2003), and quality of earnings (Francis et al., 2005). All the models confirm the dominant role of the market portfolio in explaining asset returns, but also demonstrate the importance of the added factors.

The growth of stock markets in other developed nations in the 1970s in tandem with the US market's decreasing share of the world market capitalization triggered the need for internationally compatible asset pricing models. In particular, the need for international models was prompted by the difference in the consumption and investment opportunity sets available to investors in different markets (Stulz, 1984). Moreover, deviation from purchasing power parity (PPP) among nations exposes investors to another dimension of risk that of currency exchange risk (Solnik, 1974). Under these conditions, investors in different countries are expected to use different indices to evaluate assets and may arrive at different values for the same asset (Adler and Dumas, 1983). Nevertheless, despite the differences between the US and 
other developed markets, the extension and customization of models to the settings in the markets outside the US was made easier by their full integration with the US market.

In recent decades, emerging markets, the markets associated with developing nations, have come to the fore as attractive investment destinations for investors around the globe. These markets offer higher expected returns as they are experiencing higher growth rates and the potential for the diversification of the risks in global portfolios as they are partially integrated with the developed markets (Bekaert and Harvey, 1995; Soenen and Johnson, 2008). However, the same partial integration coupled with the structural differences between emerging and developed markets (Demirtas and Zirek, 2011; Pereiro, 2010) poses unique challenges in customizing asset pricing models to the local settings. The initial asset pricing studies in this area propose the use of sovereign risk as an additional factor (Godfrey and Espinosa, 1996; Grandes et al., 2010) which is confuted by Sabal (2004) on the grounds that such an addition undermines the differences in riskiness of the individual firms in a market and assumes that the sovereign risk is non-diversifiable.

In addition, emerging markets are characterized by lower market liquidity and higher exposure to exchange rate fluctuations. These factors are not unique to emerging markets, but their nature in these markets is different from that in developed markets. The pervasiveness of the market illiquidity is reported by Bekaert et al. (2007) and Hearn et al. (2010) and that of the exchange rate by Phylaktis and Ravazzolo (2004) and Carrieri et al. (2006a and 2006b).

Several studies of asset pricing models for emerging markets have empirically tested the factor models of Fama and French, Carhart et al., and Francis et al. The studies report that the factors in these models are priced in emerging markets. The findings are in agreement with Rouwenhorst's (1999) assertion that the drivers of stock returns in emerging markets are qualitatively similar to those in developed markets. Nonetheless, these studies ignore the debilitating effects on the modelling of asset prices that stem from emerging markets' structural differences from and partial integration with developed markets.

\section{References}

Adler, M., \& Dumas, B. (1983). International Portfolio Choice And Corporation Finance: A synthesis. The Journal of Finance, 38(3), 925-984. Amihud, Y. (2002). Illiquidity And Stock Returns: Cross-Section And Time-Series Effects. Journal of Financial Markets, 5(1), 31-56.

Ball, R. (1978). Anomalies In Relationships Between Securities' Yields And Yield-Surrogates. Journal of Financial Economics, 6(2), 103-126.

Banz, R. W. (1981). The Relationship Between Return And Market Value Of Common Stocks. Journal of Financial Economics, 9(1), 3-18.

Barry, C. B., Goldreyer, E., Lockwood, L., \& Rodriguez, M. (2002). Robustness Of Size And Value Effects In Emerging Equity Markets, 1985-2000. Emerging Markets Review, 3(1), 1-30.

Basu, S. (1983). The Relationship Between Earnings' Yield, Market Value And Return For NYSE Common Stocks: Further Evidence. Journal of Financial Economics, 12(1), 129-156.

Bekaert, G., \& Harvey, C. R. (1995). Time-Varying World Market Integration. The Journal of Finance, 50(2), 403-444.

Bekaert, G., \& Harvey, C. R. (1997). Emerging Equity Market Volatility. Journal of Financial Economics, 43(1), 29-77.

Bekaert, G., Harvey, C. R., \& Lundblad, C. (2007). Liquidity And Expected Returns: Lessons From Emerging Markets. Review of Financial studies, 20(6), 1783-1831. Bhandari, L. C. (1988). Debt/Equity Ratio And Expected Common Stock Returns: Empirical Evidence. The Journal of Finance, 43(2), 507-528.

Black, F. (1972). Capital Market Equilibrium With Restricted Borrowing. The Journal of Business, 45(3), 444-455.

Carhart, M. M. (1997). On Persistence In Mutual Fund Performance. The Journal of Finance, 52(1), 57-82.

Carrieri, F., Errunza, V., \& Majerbi, B. (2006). Does Emerging Market Exchange Risk Affect Global Equity Prices?. Journal of Financial and Quantitative Analysis, 41(03), 511-540.

Carrieri, F., Errunza, V., \& Majerbi, B. (2006). Local Risk Factors In Emerging Markets: Are They Separately Priced?. Journal of Empirical Finance, 13(4), 444-461.

Chen, N.-F., Roll, R., \& Ross, S. A. (1986). Economic Forces And The Stock Market. The Journal of Business, 59(3), 383-403.

Connor, G. (1984). A Unified Beta Pricing Theory. Journal of Economic Theory, 34(1), 13-31.

Daniel, K., \& Titman, S. (1997). Evidence On The Characteristics Of Cross Sectional Variation In Stock Returns. The Journal of Finance, 52 (1), 1-33.

Dash, S. R., \& Mahakud, J. (2013). A Comparative Assessment Of Unconditional Multifactor Asset-Pricing Models: Evidence From Indian Stock Market. Journal of Management Research, 13(1), 35-54.

De Santis, G. (1997). Stock Returns And Volatility In Emerging Financial Markets. Journal of International Money and Finance, 16(4), 561-579.

Demirtas, K. O., \& Zirek, D. (2011). Aggregate Earnings And Expected Stock Returns In Emerging Markets. Emerging Markets Finance \& Trade, 47(3), 4-22.

Drew, M. E., \& Veeraraghavan, M. (2002). A Closer Look At The Size And Value Premium In Emerging Markets: Evidence From Kuala Lumpur Stock Exchange. Asian Economic Journal, 16(4), 337-351.

Drew, M. E., \& Veeraraghavan, M. (2003). Beta, Firm Size, Book-To-Market Equity And Stock Returns - Further Evidence From Emerging Markets. Journal of the Asia Pacific Economy, 8(3), 354-379.

Dumas, B., \& Solnik, B. (1995). The World Price Of Foreign Exchange Risk. The Journal of Finance, 50(2), 445-479.

Fama, E. F. (1996). Multifactor Portfolio Efficeincy And Multifactor Asset Pricing. Journal of Finance and Quantitative Analysis, 31(4), 441-465.

Fama, E. F., \& French, K. R. (1992). The Cross-Section Of Expected Stock Returns. The Journal of Finance, 47(2), 427-465.

Fama, E. F., \& French, K. R. (1993). Common Risk Factors In The Returns On Stocks And Bonds. Journal of Financial Economics, 33(1), 3-56.

Fama, E. F., \& French, K. R. (1995). Size And Book-To-Market Factors In Earnings And Returns. The Journal of Finance, 50(1), 131-155.

Fama, E. F., \& French, K. R. (1996). Multifactor Explanations Of Asset Pricing Anomalies. The Journal of Finance, 51(1), 55-84.

Fama, E. F., \& French, K. R. (1998). Value Versus Growth: The International Evidence. The Journal of Finance, 53(6), 1975-1999.

Francis, J., LaFond, R., Olsson, P., \& Schipper, K. (2005). The Market Pricing Of Accruals Quality. Journal of Accounting and Economics, 39(2), $295-327$.

Godfrey, S., \& Espinosa, R. (1996). A Practical Approach To Calculating Costs Of Equity Investment In Emerging Markets. Journal of Applied Corporate Finance, $9(3), 80-90$.

Grandes, M., Panigo, D. T., \& Pasquini, R. A. (2010). On The Estimation Of Cost Of Equity in Latin America. Emerging Market Review, 11(4), 373-389.

Hansen, Lars P., and Ravi Jagannathan, (1991), Implications of Security Market Data for Models of Dynamic Economies. Journal of Political Economy, 99: 225-262

Harvey, C. R. (1995). The Risk Exposure Of Emerging Equity Markets. World Bank Economic Review, 9(1), 19-50.

Hearn, B., Piesse, J., \& Strange, R. (2010). Market Liquidity And Stock Size Premia In Emerging Financial Markets: The Implications For Foreign Investment. International Business Review, 19(5), 489-501.

Ikeda, S. (1991). Arbitrage Asset Pricing Under Exchange Risk. The Journal of Finance, 46(1), 447-455.

Jagannathan, R., \& Wang, Z. (1996). The Conditional CAPM And The Cross-Section Of Expected Returns. The Journal of Finance, 51 (1), 3-53.

Jegadeesh, N., \& Titman, S. (1993). Returns To Buying Winners And Selling Losers: Implications For Stock Market Efficiency. The Journal of Finance, 48(1), 65-91.

Jensen, M. C., Black, F., \& Scholes, M. S. (1972). The Capital Asset Pricing Model: Some Empirical Tests. In Studies in the Theory of Capital Markets, Praeger Publishers Inc.

Jun, S. G., Marathe, A., \& Shawky, H. A. (2003). Liquidity And Stock Returns In Emerging Equity Markets. Emerging Markets Review, 4(1), 1-24.

Koedijk, K. G., Kool, C. J., Schotman, P. C., \& Van Dijk, M. A. (2002). The Cost Of Capital In International Financial Markets: Local Or Global?. Journal of International Money and Finance, 21(6), 905-929. 
Lakonishok, J., Shleifer, A., \& Vishny, R. W. (1994). Contrarian Investment, Extrapolation, And Risk. The Journal of Finance, 49(5), 1541-1578.

Lintner, J. (1965). Security Prices, Risk, And Maximal Gains From Diversification. The Journal of Finance, 20(4), 587-615.

Markowitz, H. (1952). Portfolio Selection. The Journal of Finance, 7(1), 77-91.

Merton, R. C. (1973). An Intertemporal Capital Asset Pricing Model. Econometrica, 41(5), 867-887.

Pastor, L., \& Stambaugh, R. F. (2003). Liquidity Risk And Expected Stock Returns. Journal of Political Economy, 111(3), 642-685.

Pereiro, L. E. (2010). The Beta Dilemma In Emerging Markets. Jounal of Applied Corporate Finance, 22(4), $110-123$.

Phylaktis, K., \& Ravazzolo, F. (2004). Currency Risk In Emerging Equity Markets. Emerging Markets Review, 5(3), $317-339$.

Reilly, F. K., \& Brown, K. C. (2003). Investment Analysis \& Portfolio Management, seventh ed. Thompson Southwestern, Mason, OH.

Rosenberg, B., Reid, K., \& Lanstein, R. (1985). Persuasive Evidence Of Market Inefficiency. Journal of Portfolio Management, $11,9-17$.

Ross, S. A. (1976). The Arbitrage Theory Of Capital Asset Pricing. Journal of Economic Theory, 13(3), 341-360.

Rouwenhorst, K. G. (1999). Local Return Factors And Turnover In Emerging Stock Markets. The Journal of Finance, 54(4), $1439-1464$.

Sabal, J. (2004). The Discount Rate In Emerging Markets: A guide. Journal of Applied Corporate Finance, 16(2-3), 155-166.

Sercu, P. (1980). A Generalization Of The International Asset Pricing Model. Revue de l'Association Française de Finance, 1(1), 91-135.

Sercu, P., \& Uppal, R. (1995). International Financial Markets and The Firm. South-Western College Publishing.

Shanken, J. (1982). The Arbitrage Pricing Theory: Is It Testable? The Journal of Finance, 37(5), 1129-1141.

Sharpe, W. F. (1964). Capital Asset Prices: A Theory Of Market Equilibrium Under Conditions Of Risk. The Journal of Finance, $19(3), 425-442$.

Soenen, L., \& Johnson, R. (2008). The Equity Market Risk Premium And The Valuation Of Overseas Investments. Journal of Applied Corporate Finance, 20(2), 113121.

Solnik, B. (1983). International Arbitrage Pricing Theory. The Journal of Finance, 38(2), 449-457.

Solnik, B. H. (1974). An Equilibrium Model Of The International Capital Market. Journal of Economic Theory, 8(4), $500-524$.

Stattman, D. (1980). Book values and stock returns. In the Chicago MBA: A Journal of Selected Papers, 4, 25-45.

Stulz, R. M. (1984). Pricing Capital Assets In An International Setting: An Introduction. Journal of International Business Studies, 15(3), 55-73.

Unlu, U. (2013). Evidence to Support Multifactor Asset Pricing Models: The Case of The Istanbul Stock Exchange. Asian Journal of Finance \& Accounting, 5(1), 197208.

Wei, K. J. (1988). An Asset-Pricing Theory Unifying the CAPM and APT. The Journal of Finance, 43(4), 881-892. 